NBER WORKING PAPER SERIES

\title{
PHYSICAL ACTIVITY: ECONOMIC AND POLICY FACTORS
}

\author{
Melayne M. McInnes \\ Judith A. Shinogle \\ Working Paper 15039 \\ http://www.nber.org/papers/w15039
}

\author{
NATIONAL BUREAU OF ECONOMIC RESEARCH \\ 1050 Massachusetts Avenue \\ Cambridge, MA 02138 \\ June 2009
}

We thank Jim Sallis and participants at the NBER Conference on Economic Aspects of Obesity for excellent comments and Chad Cotti for sharing data on sin taxes. The views expressed herein are those of the author(s) and do not necessarily reflect the views of the National Bureau of Economic Research.

NBER working papers are circulated for discussion and comment purposes. They have not been peerreviewed or been subject to the review by the NBER Board of Directors that accompanies official NBER publications.

(C) 2009 by Melayne M. McInnes and Judith A. Shinogle. All rights reserved. Short sections of text, not to exceed two paragraphs, may be quoted without explicit permission provided that full credit, including (๑) notice, is given to the source. 
Physical Activity: Economic and Policy Factors

Melayne M. McInnes and Judith A. Shinogle

NBER Working Paper No. 15039

June 2009

JEL No. I1

\begin{abstract}
$\underline{\text { ABSTRACT }}$
While much research has focused on the costs of obesity and economic factors that drive obesity growth, little economic research has examined the factors that contribute to obesity - physical inactivity and poor nutrition. This paper will examine correlates and predictors of physical activity over time with emphasis on economic factors. We use data for adults from the 2000-2005 Behavioral Risk Factor Surveillance System (BRFSS) survey that includes state and county codes for each individual that allows us to add supplementary data on state beer and cigarette taxes, local transportation costs, availability of gyms and recreational facilities, county unemployment, crime rates, and prices of related goods. We find that income and education has a strong and consistently positive effect on physical activity across specifications. Sin taxes have no effect on the likelihood of any exercise but generally have negative effects on vigorous exercise or moderate and vigorous exercise. Physical activity is more likely when there are more parks per capita in a county. Our results above are robust to the inclusion of weight status and use of flu shots (a measure of an individual's tendency towards prevention).
\end{abstract}

Melayne M. McInnes

Department of Economics

Moore School of Business

University of South Carolina

(4th floor, Close Building)

1705 College Street

Columbia, SC 29208

mcinnes@moore.sc.edu

Judith A. Shinogle

University of Maryland, Baltimore County

Maryland Institute for Policy Analysis and Researc

1000 Hilltop Circle

430 Public Policy

Baltimore, MD 21250

shinogle@umbc.edu 


\section{Introduction}

Obesity has risen to epidemic levels in the U.S. with the prevalence among adults increasing from 15 percent in 1976-1980 to 31 percent in 1999-2000 (Flegal et al., 2002). The economic effects of obesity may outweigh other health risk factors such as smoking and alcoholism (Sturm, 2002) as obesity is estimated to increase annual medical expenditures by 37 percent (Finkelstein et al. 2003). While much research has focused on the costs of obesity and economic factors that drive obesity growth, little economic research has examined the factors that contribute to obesity - physical inactivity and poor nutrition. This paper will examine correlates and predictors of physical activity over time with emphasis on economic factors. Using data for adults from the 2000-2005 Behavioral Risk Factor Surveillance System (BRFSS) survey, we examine the characteristics of individuals and their environments that determine their level of activity. Because BRFSS includes state and county codes for each individual, we are able to include additional information regarding economic variables such as area unemployment as well as price and supply variables.

\section{Background}

As more attention has been focused on the rising levels of obesity (defined as a Body Mass Index, BMI, of 30 or greater) in the US, it is important to consider whether obesity trends are due rising caloric intake, falling levels of activity or both. Many studies have considered the economic factors that drive the obesity epidemic and caloric intake (Cutler et al. 2003, Anderson P, et al., 2003; Rashad, 2006; Smith et al, 2005; Bleich et al., 2007; Rashad and Markowitz, 2007; Baum and Ruhm, 2007; Philipson, 2001; Chou et al., 2004), but the physical activity side of the equation has received comparatively little attention. Even if changes in physical activity are not to blame for the dramatic changes in obesity, policies aimed at increasing physical activity may be a part of the solution. Understanding the 
determinants of physical activity is an important first step in determining whether policies aimed at increasing physical activity levels can be useful levers in reducing overall obesity levels.

\section{Physical Activity and Health}

Physical activity has unique health consequences. Murphy et al (2007) find that activity as minimal as walking improves blood pressure control, lowers body fat percentages and decreases BMI. Church et al (2007) examines postmenopausal women with high blood pressure and finds that physical activity, even at low doses, improves cardiorespiratory fitness no matter the weight of the person. Other health research on the effects of obesity is starting to find that activity levels are important predictors of outcomes. Katzmarzyk et al (2004) find adding cardiorespiratory fitness to models comparing mortality (all cause and cardiovascular deaths) for men with metabolic syndrome to healthy men causes the association to be insignificant. They find that cardiorespiratory fitness provides a strong protective effect.

Besides examining health effects of physical activity, other researchers have estimated the impact of inactivity on medical expenditures. Keeler et al (1989) found that those with sedentary lifestyles incur higher medical costs, but their life expectancy is less so they collect less public and private pensions. At a 5 percent rate of discount for future dollars, the lifetime subsidy from others to those with a sedentary life style was estimated at $\$ 1,900$. One more recent study has examined the cost of inactivity to a health plan. Garret et al (2004) utilizing a cost of illness methodology finds that inactivity cost $\$ 86$ million in one health plan. Another study utilizes the disease by disease approach examines the impact of in activity in Canada. Katzmarzyk et al (2000) find that 2.5 percent of total direct health care costs in Canada in 1999 are attributable to physical inactivity. They further estimate that approximately 21,000 lives were lost prematurely in 1995 due to inactivity. Pratt et al (2000) use the 1987 National 
Medical Expenditure Survey to perform a stratified analysis of medical expenditures and find that people who were physically active report an adjusted average annual medical expenditure of $\$ 1,019$ compared to $\$ 1,349$ for those who report being inactive. Shinogle (2008) uses linked National Health Interview Survey (NHIS) to Medical Expenditure Panel Survey (MEPS) to estimate the inactivity attributable fraction of medical expenditures range from 11 percent to 16 percent. In these models, inactivity did not significantly increase the probability of a medical expenditure but did increase the level of expenditures. This result may reflect that physically active people have an unobserved taste for preventive health measures. This taste for prevention services is also indicated in the following analysis of 2000-2005 National Health Interview Survey. Examining office based visits by physically active (defined as Center for Disease Control and Prevention, $C D C$ ) we find that active people are more likely to have 1 to 2 visits but less likely to have higher number of office based visits in the past 12 months. On the other hand, examining emergency room visits and number of overnight hospital days, we find the opposite association, physically active people have fewer of these more expensive medical use.

\section{Number of Office Visits in Past 12 Months for Regularly Active vs. Not Regularly Active}

\begin{tabular}{rrr}
\hline $\begin{array}{c}\text { Number of Office Visits } \\
\text { in Past 12 Months }\end{array}$ & $\begin{array}{c}\text { Not Regularly } \\
\text { Active }\end{array}$ & Regularly Active \\
0 & $20.1 \%$ & $17.8 \%$ \\
1 & $15.5 \%$ & $18.7 \%$ \\
2 to 3 & $23.5 \%$ & $28.0 \%$ \\
4 to 5 & $13.8 \%$ & $13.8 \%$ \\
6 to 7 & $7.1 \%$ & $6.6 \%$ \\
8 to 9 & $4.0 \%$ & $3.2 \%$ \\
10 to 12 & $6.5 \%$ & $5.0 \%$ \\
13 to 15 & $2.6 \%$ & $1.9 \%$ \\
16 or more & $6.9 \%$ & $5.0 \%$ \\
\hline
\end{tabular}


vs. Not Regularly Active

\begin{tabular}{rrr}
\hline $\begin{array}{c}\text { Number of ER Visits in } \\
\text { Past 12 Months }\end{array}$ & $\begin{array}{c}\text { Not Regularly } \\
\text { Active }\end{array}$ & Regularly active \\
0 & $78.11 \%$ & $81.81 \%$ \\
1 & $13.52 \%$ & $12.81 \%$ \\
2 to 3 & $5.92 \%$ & $4.23 \%$ \\
4 to 5 & $1.35 \%$ & $0.65 \%$ \\
6 to 7 & $0.48 \%$ & $0.21 \%$ \\
8 to 9 & $0.17 \%$ & $0.09 \%$ \\
10 to 12 & $0.22 \%$ & $0.10 \%$ \\
13 to 15 & $0.06 \%$ & $0.03 \%$ \\
16 or more & $0.15 \%$ & $0.06 \%$ \\
& p< 0.001 & \\
\hline
\end{tabular}

\section{Number of Times in Hospital Overnight in Past 12 Months by} Regularly Active vs. Not Regularly Active

\begin{tabular}{crr}
\hline $\begin{array}{c}\text { Number of Times in } \\
\text { Hospital Overnight in } \\
\text { Past 12 Months }\end{array}$ & $\begin{array}{c}\text { Not Regularly } \\
\text { Active }\end{array}$ & Regularly Active \\
0 & & \\
1 & $88.4 \%$ & $92.8 \%$ \\
2 & $8.4 \%$ & $5.9 \%$ \\
3 & $1.9 \%$ & $0.9 \%$ \\
$>3$ & $0.7 \%$ & $0.2 \%$ \\
& $0.6 \%$ & $0.2 \%$ \\
\hline
\end{tabular}

Source: Shinogle 2008.

\section{Trends in Physical Activity}

In light of the obesity epidemic, it is perhaps surprising that Americans are spending more of their time and income on leisure and at least some of that is going to physical activity (Sturm 2004). Between 1965 and 2000, industries catering to leisure activity are generally growing more quickly than the overall economy, but a disproportionate share of this growth is in sedentary activities (such as cable t.v. viewing) rather than more active pursuits (sports clubs, dance studios). Nonetheless, time spent in physical activity is increasing. Sturm's analysis shows that between 1990 and 2000, the median increase in reported physical activity is 20 minutes per week. While most Americans still do not meet federal recommendations for physical activity, the CDC (2004) reports that between 1988 and 2002, there has been a 9 percentage point drop in the prevalence of no leisure-time physical activity. Estimates of 
physical activity trends vary depending on survey and questions used. As shown in table below, the National Health Interview Survey (NHIS) finds around 30 percent of the adult population is inactive. This can be compared to estimates from the BRFSS showing that approximately 75 percent of the adult population participates in any leisure time physical activity in the past 30 days. While it is encouraging that the majority of Americans report getting some physical activity, a much lower percent report regularly engaging in moderate or vigorous exercise. BRFSS estimates that approximately 25 percent of population is involved in vigorous physical activity while 45 percent are involved in moderate or vigorous physical activity.

Estimates of Physical Activity from Two Surveys 2001 - 2005

Percent of Adult Population

\begin{tabular}{lrrrrr}
\hline & $\mathbf{2 0 0 1}$ & $\mathbf{2 0 0 2}$ & $\mathbf{2 0 0 3}$ & $\mathbf{2 0 0 4}$ & $\mathbf{2 0 0 5}$ \\
NHIS: "inactive" & 29.9 & 30.1 & 29.5 & 30.4 & 29.3 \\
& & & & & \\
BRFSS: "any exercise" & 75.88 & 76.94 & 77.2 & 77.26 & 77.64 \\
BRFSS: "vigorous PA" & & & 25.01 & & 24.53 \\
BRFSS: "moderate or vigorous PA" & & & 45.56 & & 45.71
\end{tabular}

Source: Authors' tabulations from NHIS and BRFSS

\section{Physical Activity and Economics}

Perhaps the most intriguing evidence of a link between physical fitness, health, and economic factors comes from Chris Ruhm's studies of age-adjusted mortality over the business cycle $(2005,2000)$. Ruhm finds that declines in mortality during temporary economic downturns are accompanied by increases in leisure time physical activity, declines in BMI and smoking. These changes disproportionately occur among the least active, most severely obese, and heaviest smokers, respectively. Ruhm's findings point to the important role that economic levers can have in shaping 
physical activity levels and the need to better understand the relationships between lifestyle behaviors such as physical activity and smoking. If there are economies of scope in reducing unhealthy behaviors, then policy makers may be able to exploit this when designing a policy that ostensibly targets only one of these behaviors.

More recently, using the BRFSS 1996 - 2000, Rashad (2007) develops a model of cycling propensity and the health gains that result. Cycling rates are lower for those who are working, those with higher incomes, and females. She also finds that cycling rates respond negatively to urban sprawl and real gas prices, and that increased cycling is associated with significant health gains.

Another important aspect in the economics of physical activity is the time constraint. Mullahy and Rober (2008) examine the 2005 and 2006 American Time Use Study to explore factors associated with time spent in physical activity. They find difference not only by gender but also by if time spent is during the week or weekends. Education is associated with increased PA on weekends/holidays for both men and women. Males show a decline in PA as they age and males with spouses have lower PA than those without. For females, PA is reduced on weekends and holidays. Further research is warranted on how shocks in time use (such as children, marriage, job change) affect PA.

\section{Physical Activity and Policy}

Policies directly aimed at promoting greater physical activity have almost exclusively focused on physical education in schools (Yancey et al., 2007). Increased physical education requirements generally do translate into more minutes of $\mathrm{PE}$, but do not appear to alter obesity levels and do not clearly increase physical activity (Cawley, 2005). Policy targeting the built environment may also promote physical activity, given studies that find the proximity and attractiveness of recreational facilities does appear to promote physical activity (Yancey et al., 2007). State and local spending on parks and recreation increases the likelihood and amount of participation in outdoor sports (Humphreys and 
Ruseki, 2007). Outdoor sports, however are a small component of physical activity (only 5 percent of BRFSS participants report participation in outdoor recreation such as backpacking, fishing, hiking, or waterskiing), and other more common forms of exercise, such as walking, were not affected by state spending levels.

The built environment is a key issue for policy aimed at increasing PA. Brownson et al (2005) examine trends in activity for leisure, work, travel and related behaviors and find that a combination of changes in the built environment and an increase proportion of the population engaging in sedentary behaviors (such as t.v. viewing) puts a significant part of the population at risk for physical inactivity. Another recent study found that counties with a Walmart are associated with lower physical activity but the BMI in these counties is actually lower than those without a Walmart. Adults in counties with Walmarts have higher fruit and vegetable consumption; lower fat consumption than counties without a Walmart. Having lower priced commodities closeby increase the purchasing power of consumers allowing for the purchase of higher cost healthier foods (Courtemanche, 2008).

Other government policies may have unintended spillover effects that indirectly promote or discourage physical activity levels. Rashad's study of cycling suggests that gas taxes may have an unintended benefit in terms of promoting physical activity. Other policies, such as those aimed at reducing smoking, may also have unintended consequences for physical activity. Clean indoor air policies and cigarette prices are both weakly associated with increased BMI (Cho, Grossman, and Saffer, 2004, 2006). Given possible interactions between lifestyle behaviors, the spillover effects from policies aimed at reducing smoking are difficult to predict. Former smokers and less intense smokers may find leisure physical activity more enjoyable and more necessary to compensate for weight gain. On the other hand, when mandated to reduce risk along one margin, individuals may choose to offset this by increasing risk along another margin (Pelzman, 1975). We discuss these effects in more detail below. 


\section{Basic Model of Economic Determinants of Physical Activity}

In a model of household production, the price of physical activity includes the opportunity cost of time and the cost of inputs to physical activity. Thus, we consider below factors that affect the individual's opportunity cost of time (such as education and income) as well as some input prices. We also consider whether environmental variables, such as availability of parks and crime rates, have an effect on physical activity levels. We also consider whether transportation costs and availability affect PA. An important question for us is whether other health behaviors are substitutes or complements with physical activity. For example if one thinks of smoking as a weight reduction device, would the decrease in smoking cause individuals to find other weight reduction behavior such as physical activity? On the other hand if smoking is an indicator for overall risky health behavior, a change in smoking would not affect physical activity. We make similar arguments for drinking.

Suppose that the individual receives utility from health $H$, physical activity $A$, and other goods $Z$ as measured by the utility function $U(H, A, Z)$. Health depends on physical activity $A$ and consumption goods Z: $H(A, Z)$. Individuals produce physical activity by combining time and other exercise inputs (gym services, exercise equipment, natural amenities, physical trainer services, etc.): $A=A\left(x_{A}, t_{A}\right)$. Time inputs include the time spent in the activity as well as any travel time incurred to get to the bike path, gym, safe neighborhood for walking, or other exercise venue.

The vector $Z$ includes goods that may be complements or substitutes for physical activity in two different pathways: i) consumption and ii) production of health. For a consumption example, a person might substitute an hour of drinking in a pub with friends for an hour of sailing depending on which is cheaper. On the production side, a person who does not value exercise for it's own sake, might increase activity levels if this were to enhance the productivity of other inputs to the health production. For example, reduced smoking may increase the productivity of exercise making the two complements in 
production. The consumer is assumed to maximize utility $\mathrm{U}(\mathrm{H}, \mathrm{A}, \mathrm{Z})$ subject to the time constraint and income constraints yielding the Langrangian

$$
L=U(H(A, Z), A, Z)-\lambda_{m}\left[\text { Income }=p_{A} X_{A}+p_{Z} X_{Z}+w X_{A}+w X_{Z}\right]-\lambda_{1}\left[24=\mathrm{t}_{\mathrm{A}}+\mathrm{t}_{\mathrm{w}}+\mathrm{t}_{\mathrm{Z}}\right]
$$

Assuming that both constraints are binding and treating $A$ as the choice variable, we can write the Lagrangian in terms of the full income constraint as:

$$
L=U(H(A, Z), A, Z)-\lambda\left[w 24=p_{A} X_{A}+p_{Z} X_{Z}+w t_{A}+w t_{Z}\right]
$$

The first order condition for the level of physical activity is then:

$$
U_{H} H_{A}+U_{A}=\lambda\left[p_{A} \partial X_{A} / \partial A+p_{A} \partial t_{A} / \partial A\right]
$$

The left-hand side shows that the marginal benefit of physical activity includes the indirect effect through the health production as well as from the direct effect from enjoyment of the activity (or disutility as individual tastes dictate.) The right-hand side measures the full price of physical activity and includes the opportunity cost of time as well as the price of physical activity inputs. This first order condition applies to individuals who engage in some physical activity, but a substantial fraction of the population will be at a corner solution with:

$$
U_{H} H_{A}+U_{A}-\lambda\left[p_{A} \partial X_{A} / \partial A+p_{A} \partial t_{A} / \partial A\right]<0
$$

The first-order condition from this simple static model, suggests several ways in which policy and price changes affect an individual's level of physical activity.

Own price. Policies that affect the full price of exercise include anything that reduces the cost of inputs to physical activity or the time cost of engaging in exercise. For example, the construction of new parks will reduce the travel time of individuals who live near the park. The built environment, which may affect the cost of exercise as well as the enjoyment of exercise, has been the subject of much study 
and the results are mixed. For example, Forsythe et al (2007) find no relationship between residential density and overall physical activity. Decreases in physical activity on the job in combination with rising wages may both increase the opportunity cost of exercise (Phillipson 2001). Our model includes measures of education, income, employment status, and county unemployment as factors that affect the opportunity cost of time. Because factors may also affect the cost of missed work due to poor health and the efficiency of health production, we do not have an unambiguous prediction of sign.

Prices of related goods. In looking at the effects of alcohol and tobacco prices on BMI and obesity, Cho, Grossman, and Saffer $(2004,2006)$ find that both weight measures increase with cigarettes prices but decrease with alcohol prices. Thus, they suggest that calories and cigarettes are substitutes while calories and alcohol are complements. The weight changes found by Cho, Grossman, and Saffer may also reflect changes in activity levels in addition to changes in caloric intake. For example, since the health benefits from exercise may ameliorate the damages from smoking and drinking, exercise may be a complement in the production of health to smoking or drinking. If that is the case, then policies that decrease smoking and drinking may decrease exercise as they no longer see the need for this offsetting health behavior. Alternatively, there may be complementarily in consumption. This may occur as one gets a pleasurable feeling from all three activities; thus, as the price increases for smoking, one may substitute with physical activity. Complementarities may also when individuals are trying to make behavioral changes. Changes in one health behavior may serve as a "gateway" for changes in other health behaviors (see Dutton et al. 2008 for an example). One may also have the "New Year's resolution effect" in that a person finds it easier to change a group of behaviors together and, thus, simultaneously decreasing smoking and drinking while increasing PA.

The above model is static and does not address the fact that some of the benefits and costs of physical activity are not immediately felt. The expression "no pain, no gain" illustrates the 
intertemporal tradeoffs that some people perceive in exercise. Other activities such as exercising, refraining from smoking, and controlling weight may share the characteristic of increasing short term disultility and long health. Hence, we might find a high degree of correlation among health behaviors due to the unobserved taste parameter of time preference in a cross-sectional analysis.

\section{Data and Methods:}

Data are from the Behavioral Risk Factor Surveillance System, a large nationally representative telephone survey of the non-institutionalized adult population administered by the Center for Disease Control and Prevention. Between 2001 and 2005 all states participated. We drop any pregnant women from the analysis as physical activity recommendations are dependent on prior physical fitness. Annual sample sizes range from approximately 112,000 to over 258,000 leading to a combined sample size of over 1 million observations when all four years are used.

We utilize three different measures of physical activity as BRFSS obtains different information each year. Annually, BRFSS asks if the person participated in ANY leisure time physical activity in the past 30 days. This is a weak measure as it could be as simple as walking once in the past thirty days. The advantage of using this measure is that the question is asked every year and can be used to measure changes over time. The second and third measure follows the definitions created by the CDC. The first measure - physical activity that is vigorous or moderate- is defined as engaging in light to moderate leisure time physical activity for great than or equal to 30 minutes at a frequency of greater than or equal to five times per week or engaging in vigorous leisure time physical activity for greater than or equal to 20 minutes at a frequency greater than or equal to three times a week. Our last measure examines those that only have vigorous physical activity. These last two measures of physical activity are only asked on odd years and thus reduce our analysis to years 2001, 2003 and 2005. 
Basic demographic data include age, age squared, race (black, white, Asian, with other race as the omitted category), Hispanic ethnicity, education (high school graduate, some college, college plus, with the omitted category less than high school graduate), eight income categories (over $\$ 75,000$ as omitted), married, and employment (unemployed, retired, student or homemaker with employed as omitted category). Some models also included two health measures: weight status (obese, overweigh, or other) and whether the individual got a flu shot. We include the flu shot as a measure of the person's tendency towards preventive care.

Data on area characteristics was obtained from a number of sources. Data on the number of establishments and employment in recreational industries and parks are obtained from the County Business Patterns Data Set from the Census. We created three measures: the number of fitness and recreation centers per 1000 individuals in a county ("gyms per capita"; NAICS code 713940), parks per 1000 individuals in a county (NAICS code 712190), and the number of other recreation areas per 1000 in a county (NAICS code for golf and country clubs 713190, ski venues 713920, marinas 713930, bowling facilities 713950, and all other 713990). Data on state tax policy for alcohol and tobacco are obtained from the Federation of Tax Administrators. We also added the American Chamber of Commerce Researchers' Association (ACCRA) data on pre-tax retail prices for tennis balls, bowling, bus fare and gas. County level crime statistics for violent crime rate (defined) and property crime rate from the FBI Uniform Crime Report System were added. County unemployment rates were obtained from the Bureau of Labor Statistics Local Area Unemployment files.

We run four different models: The first only includes basic demographics. The second model adds area characteristics with the next model adding obesity and overweight variables. The final model adds a measure of risk behavior - did the person have a flu shot in the last 12 months. We then rerun these four models adding smoking ban variables. 
Because previous studies have found differences in women and men in their physical activity participation, we reanalyzed all models stratifying by gender. In addition, as obesity and overweight is concentrated in lower income populations, we again examined our models stratifying by income.

\section{Results}

Table 1 presents the means and standard deviations for our data set. These are means averaged over the 4 years of the data and as such the PA measure differ than those presented on an annual bases in the tables above. Over these four years approximately 70 percent of our sample had any exercise. Yet few met the CDC's definition of active with only 12 percent reporting moderate or vigorous activity and only 7 percent reporting vigorous activity. Our sample is of adults, and the average age is close to 48 year old with the sample being predominantly white ( 83 percent) and female ( 58 percent of sample is female).

We begin our analysis of the data by building a baseline model of participation in any leisure time physical activity in the past 30 days. Our strategy is to begin with a small set of demographic and socioeconomic variables and then proceed by adding additional variables in groups. As we discuss in more detail below, the results are largely intuitive and robust across specifications. We then consider the same set of models stratified by gender to see whether the estimated effects differ between men

and women. Because more rigorous exercise habits are recommended in the health literature, we next consider two alternative measures of exercise: participation in vigorous exercise or participation in moderate or vigorous activity. We estimate pooled and gender-stratified models, and in these and all subsequent regressions, we include the full set of regressors. Finally we consider the effects of stratifying by income rather than gender. We report results for 8 income categories using our three measures of exercise participation: any, vigorous exercise, or moderate and vigorous. After briefly 
reviewing the results of all models, we discuss in more detail the overall findings for key variables of interest.

Baseline Model: Participation in Any Leisure Time Exercise.

Results for models of participation in any leisure time physical activity in the past 30 days are presented in Table 2. Model 1 in Table 2 includes only demographic variables and shows that the likelihood of reporting participation in any leisure physical activity decreases for those who are older, female, married, and uninsured. Those who are employed are less likely to exercise during leisure time than students and homemakers, retirees, or unemployed individuals. Greater education and income increase the odds of engaging in some exercise. Comparing coefficient estimates for the demographic variables across the columns in Table 2 shows that the estimated effects are robust to the inclusion of additional variables.

In Model 2 of Table 2, we include area variables to capture variation in local availability of exercise venues, economic conditions, and crime. While we would like to measure the causal impacts of changes in these area variables on physical activity, we interpret our coefficient estimates as correlation measures due to concerns over reverse causality. Healthy, active individuals may self-select areas with particular characteristics. While our analysis can exploit inter-temporal variation in these measures and we include state and year fixed effects in all models, our concern about endogeneity remains. To gauge the sensitivity of our area estimates to controls for health status and prevention behavior, we add measures of weight status and getting a flu shot in Models 3 and 4. 
The number of gyms per capita, parks per capita and other exercise venues per capita are all positively associated with increased exercise participation. While increased access may promote physical activity, it is also possible that exercise-prone individuals choose to live in into amenity-rich areas and businesses and municipalities build facilities where demand for them is high. Teasing these factors out is important for designing policy, but our data does not allow us to distinguish between these and other possible explanations. We find no relationship between participation in any exercise and the property crime rate or violent crime rate for an individual's crime.

Given the findings that obesity is related to cigarette prices and tax rates (Chou, Grossman, and Saffer, 2004 and 2006; Gruber and Frakes, 2005) we might expect to find a relationship between sin taxes and physical activity. In particular, the puzzling finding of Gruber and Frakes (2005) that obesity declines when cigarette taxes increase might make more sense if we found higher taxes were associated with increased exercise. As individuals smoke less, they may decide to make overall health changes and exercise more. Our results in Table 2 do not confirm this conjecture, however. We find no relationship between beer or cigarette taxes and participation in any leisure time exercise.

We do, however, find a relationship between transportation costs and exercise. Gas prices are negatively and significantly related to exercise while bus fare is positive and significant in all models but the last. One interpretation of these results is that driving one's self is a complement to leisure time physical activity while activities available to bus riders are substitutes for leisure time exercise. As an example, high gas prices may decrease car trips to the gym while increased bus fares make playing basketball at a neighborhood park cheaper relative to taking the bus to see a movie. This explanation suggests we will see a stronger effect of bus fare at the low end of the income scale. Our stratifications by income, reported below, allow us to examine this conjecture more closely. The two exercise "prices" 
we inclfude are probably poor proxies for an index of leisure time physical activity prices and we find no significant effects for these variables in any model in Table 2.

Any Exercise: Stratified by Gender.

Stratifying by gender reveals some interesting differences between the factors that affect men's and women's participation in any leisure time physical activity. We report these results in Table 3 and Table 4. First we see that the shape of the age curve is different for men and women. For men, participation decreases with age at a diminishing rate, while for women age is positively associated with exercise for younger women in our sample but eventually decreases participation at an increasing rate. In examining price factors, one difference we find is some significance for the price of bowling for women but this effect in not precisely estimated in our preferred model (Model 5). Our measures of exercise venues per capita have the same signs but are not always significant in the stratified regression. This may be due to the lack of precession in these measures. In Model 5, we find that gyms per capita are significant for men but not women, parks per capita is not significant, and other exercise venues (e.g. ski areas and marinas) continue to be significant for both. This may indicate that people locate in areas that have the activity amenities they desire (skiing, boating etc). Perhaps the most interesting difference is the effect of overweight status. In the pooled regression, we found overweight to be negative and significant but it becomes positive and significant when we look at only men. Concern exists regarding the accuracy of BMI in diagnosing obesity. A study found that BMI had a better correlation with lean mass than body fat percentages (Romero-Corral et al, 2008); hence, active men with high muscle mass may be misclassified as overweight. 
Results for Models of Vigorous Exercise.

In Table 5 we report the results for our preferred model using participation in vigorous exercise as the dependent variable. The effects of demographic variables are qualitatively the same as for any exercise with the exception of some of the race and ethnicity variables. For men, we find no difference in participation in vigorous activity between whites, blacks, Asians and the omitted category -other races, nor did we find any difference for Hispanic ethnicity. The effect of being insured is no longer significant. Similar to what we found for any activity, we find that participation in vigorous activity is negatively and significantly related to the price of gas but positively related to bus fare. We expect tennis to be a larger component of vigorous exercise than any exercise, but we find a positive effect of the price of tennis balls on participation in vigorous activity. This may be due to fact that the price of tennis balls is a small component of the total price of tennis (court fees, time costs, racquet costs). The effects of gas prices (), bus fare (+), and crime (0) remain the same as before, but county unemployment is no longer significant. Sin taxes now have a negative and significant effect on vigorous exercise (with the exception of cigarette taxes for men), indicating that higher taxes are associated with decreases in vigorous activity. While higher sin taxes may lead to reductions in smoking and drinking, there do not appear to be positive spillovers to exercise. Parks per capita are never significant, and gyms or other recreational amenities per capita are significant for women but not men. Overweight and obese are negative and significant across all specifications, while flu shots are positive and significant for the pooled sample and the men.

\section{Results for Models of Vigorous and Moderate Exercise}

Table 6 shows the results when the dependent variable is moderate or vigorous physical activity (PA). Insurance is negatively related to the probability of engaging in vigorous or moderate physical activity 
for the pooled sample and females. The price of tennis balls and bowling have opposite effects on this measure of PA (+ and -, respectively). We continue to find that gas prices are associated with less exercise while bus fare has a positive association. Property crime rates are negatively associated with exercise for the pooled sample and men, but there is no significant association with violent crime rates. The measures of recreation facilities per capita are generally positively and significantly associated with engaging in vigorous or moderate exercise. Cigarette and beer taxes are negative and significant factors (with the exception of the cigarette tax for women). Thus, we find no evidence that individuals change health behaviors together in response to a change in the price of smoking or drinking. Indeed, our results indicate that vigorous physical activity declines as either beer or cigarette taxes increase. With respect to the health variables, overweight and obese are both negatively related to exercise while the preventive health measure (flu shots) is positive for the pooled sample and men.

\section{Stratification by Income Category}

We report the results stratified by income in Table 7. While the coefficients of most demographic and socioeconomic variables in the model for participation in any leisure time exercise are stable across income categories, the effects of some variables do change. The effects of being married, retired, or a student or homemaker appear to have a larger impact at lower incomes than higher ones. The effect of being insured is generally positive with stronger effects as income increases. The effects of gender, race variables, and education variables do not appear to vary with income. Based on our findings above that physical activity decreases when gas prices are high (or bus fares low), we expected to find stronger price effects at low incomes where prices presumably bite. Instead, we find gas prices are not a significant factor for any income group, and we find a significant positive effect of bus fare only for income category 4 (Income $\$ 20 \mathrm{~K}<25 \mathrm{~K}$ ). The county unemployment rate and county crime rates have a 
negative effect where significant but there is no apparent pattern by income. Similarly, exercise and recreation venues per capita are positive when significant but the effects are nil for most income categories and no pattern emerges. Taxes have no effect for any income category. In looking at weight measures, it appears that the effect of being overweight are felt at the higher income categories only while obese has a stable negative effect across all income categories. Flu shots also have a robust positive effect across income categories.

\section{Conclusions:}

In this chapter we examine of factors associated with variation in leisure time physical activity. To explore these associations, we model three levels of leisure time physical activity - any exercise, physical activity that is moderate or vigorous, and vigorous physical activity. Our preferred specification includes state, year and month fixed effects as well as controls for area level recreation amenities, area crime rates, prices for related goods and a measure of weight and preventive health -flu shots.

The estimated effects of socioeconomic factors are robust across model and exercise measure. We find that income has a strong and consistently positive effect on physical activity across specifications. Education is also a positive and significant factor in all models. We also find the effects of education are fairly stable across gender and income. In almost every model, we find that individuals who report being Hispanic are less likely to exercise with the effect being largest when income is low. Being married generally decreases participation in physical activity by either measure. For any exercise, the effect appears to be driven by those with lower income and women. For vigorous exercise, the effects of marriage are about the same for men and women. Holding marital status constant, men are more likely to exercise than women across all income levels. Individuals who work are less likely to engage in exercise by any measure than those who are unemployed, retired, or out of the labor force, and the effect for any exercise appears to be larger when income is low. To better understand these 
results, we would like to have better measures of the time constraints affecting men and women including family size. Unfortunately the BRFSS does not have a consistent measure of family size across the years of our data.

The effects of area-specific variables are also largely consistent across our specifications. These coefficients must be interpreted with caution because individuals who are likely to exercise may choose to live in areas with certain amenities and characteristics. We do not find that exercise levels vary with the two direct "own" price measures (price of tennis balls and price of bowling balls), but we do find a relationship between transportation costs and exercise. Gas prices are negatively and significantly related to leisure time exercise while bus fare is positive and significant in most models of participation in any leisure time exercise or vigorous exercise. Contrary to what we might have expected, the effects of gas and bus fare do not differ by income. The magnitudes of the effects differ by gender: bus fare has a bigger impact on women while gas prices have a bigger effect on men. The results may point to problems in the way physical activity is measured in the BRFSS. While the survey question specifies leisure time exercise, respondents may include transportation exercise (walking) as part of this response. Another concern is the merging of the price data is at a too gross of a level. Price and area measures may need to be at a census tract or lower area level which is not available on this data set.

Sin taxes have no effect on the likelihood of any exercise but generally have negative effects on vigorous exercise or moderate and vigorous exercise. This suggesting inactivity and smoking (or drinking) are substitutes. People who are forced to become healthier in one dimension due to the higher taxes may be able to relax in another area and still keep health stock at the target level.

We find that an individual is more likely to participate in physical activity when unemployment in the county is low. This is surprising given Ruhm's (2005) results that leisure time physical activity increases during economic downturns; however, the results are not directly comparable. Ruhm uses 
average state unemployment levels in the previous three months while we use the annual county unemployment rate, and his measure of physical activity excludes those who engage in "irregular" exercise. When our dependent variable is vigorous exercise (as in table 2, model 1 ) or moderate or vigorous physical activity (as in table 2, model 2 ), we find that the unemployment variable while still negative, is now no longer significant. We find a weak relationship between violent crimes and participation in exercise and no effect from property crime rates. Physical activity is more likely when there are more parks per capita in a county, which is consistent with Humphrey and Ruseki's (2007) findings using state-level variation in total state and local spending on parks is positively associated with outdoor activity.

Our results above are robust to the inclusion of weight status and use of flu shots. Being overweight is generally associated with decreased exercise but there are some interesting exceptions when we stratify by income or gender. Overweight is positive and significant when we look at any exercise for men, though this effect reverses when we restrict attention to vigorous exercise. For either exercise measure, we find that effects of overweight are not significant at lower incomes. Obesity, on the other hand, is negatively associated with physical activity across the board. Individuals who get flu shots are generally more likely to report some exercise. While these measures are likely endogenous, we find that their inclusion does not affect the other results. If the area variables above were measuring the reverse causation that people who are active move to areas with low crime rates and high spending on parks, then we might expect that adding measures of health status and taste for preventive medicine would reduce the effects of these variables.

Our results can be compared to Rashad's (2007) analysis of cycling rates using the 1996-2000 BRFSS data and Humphrey and Ruseki's analysis of participation in five categories of leisure time physical activity (outdoor recreation, household activities, group sport, individual sport and walking) 
using the 1998 and 2000 BRFSS. While our demographic results are largely consistent with both studies, the Humphrey and Ruseki study shows that demographic effects can differ widely across activity categories.

The most important limitation in our study is due to the measures of physical activity. The BRFSS measure is based on self-report, and PA measures are not consistent across surveys making it difficult to directly compare results. In addition, the most consistent PA variable (any exercise) does not conform to the CDC definitions for physical activity. The CDC measures of moderate or vigorous activity (which do conform to measures) are only captured in two years of our data. The results are also limited to analyzing only leisure time physical activity. Any physical activity is beneficial and future studies need to include measure of activity for transportation and work. Future work will examine the effects of area variables on other data sets such as the National Health Interview Survey to examine more appropriate definition of physical activity. In addition measures of park access gym data are at the county level which may be too large of a geographical dimension to capture the causal impact of increased access. Studies such as Sandy et al in this volume that allow detailed description of the neighborhood may be more appropriate. We are also missing measures of home exercise such as purchasing of exercise equipment or videos that may influence leisure time activity.

\section{Policy Implications:}

The strong relationship we find between education and exercise suggests that there may be positive spillovers from policies aimed at increasing educational attainment. Education aimed at increasing the awareness of the value of PA in the form as Public Service Announcements as advocated by Pratt et al (2004) should be explored further. We also find income is positively associated with exercise. Our results also show that working individuals are less likely to exercise than those who are unemployed or out of the labor force, and that men are more likely to exercise than women. These 
reflect the importance of the time constraint in physical activity. Policies aimed to allow more time or flexibility in time may improve leisure time physical activity. Greater flexibility in working hours, providing jobsite exercise opportunities, and increasing access to childcare are all possible avenues for promoting physical activity. Designing appropriate policies will require a better understanding of how time constraints, income, education, and gender interact in determining physical activity. Two recent papers looking at time use (Mullahy and Rober, 2008) and time constraints (Loh, 2009) are important first steps in this analysis.

We find that certain area characteristics such as access to gyms, parks and other recreational facilities increase the probability of exercise for adults. These effects remain consistent even when we include measures for unobservable tastes such as flu shots. We do not find that these results are robust to income stratification, thus recreation stamps to subsidies the low income to attend gyms as advocated by Pratt et al (2004) may not improve the amount of leisure time physical activity.

Finally, further investigation is warranted on the interaction between various health behaviors. While here are contradictory findings about the association between smoking and obesity (Chou, Grossman, and Saffer, 2004 and 2006; Gruber and Frakes 2005; Cawley et al 2003), our findings suggest that smoking and physical activity may be substitutes and would be consistent with increased obesity due to higher cigarette taxes/prices. We also find that higher beer taxes lead to lower activity levels. Future research should examine the interaction between smoking, alcohol consumption, dietary behavior and physical activity.

\section{References:}

Anderson, Patricia M., Kristin F. Butcher and Phillip B. Levine. 2003. Maternal employment and overweight children, Journal of Health Economics 22(3), 477-504.

Baum, Charles L and Christopher J. Ruhm. 2007. Age, Socioeconomic Status, and Obesity Growth, NBER Working Paper 13289. 
Bleich, Sara, David M. Cutler, David M., Christopher J. Murray, and Alyce Adams. 2007. Why is the Developed World Obese? NBER Working Paper No. W12954 Available at SSRN: http://ssrn.com/abstract=971589

Brownson R.C., T.K. Boehmer, D.A. Luke . 2005. Declining Rates of Physical Activity in the United States: What are the Contributors? Annual Review of Public Health. 26:421-443.

Caban-Martinez, Alberto J., David J. Lee, Lora E. Flemming, William G. Le Blanc, Krotopher L. Arheart, Katherine Chung-Bridges, Sharon L. Christ, Katherine E. McCollister, Terry Pitman. 2007. Leisuretime Physical Activity Levels of the US Workforce, Preventive Medicine 44, 432-436.

Cawley, John, Chad Meyerhoefer, and David Newhouse. 2005. The Impact of State Physical Education Requirements on Youth Physical Activity and Overweight, Health Economics 16(2): 1287-301.

Cawley John, Sara Markowitz S, John Tauras. 2003. Lighting Up and Slimming Down: The effects of bodyweight and cigarette prices on adolescent smoking initiation, Journal of Health Economics 23(2):293-311.

Center for Disease Control and Prevention. 2004. Prevalence of No Leisure-time Physical Activity Levels-35 States and The District of Columbia, 1988-2002, MMWR Morbidity Mortality Weekly Report 53, 83-86.

Chou, Shin-Yi, Michael Grossman and Henry Saffer. 2004. An economic analysis of adult obesity: results from the Behavioral Risk Factor Surveillance System, Journal of Health Economics 23(3), 565587.

Chou, Shin-Yi, Michael Grossman and Henry Saffer. 2006. Reply to Jonathan Gruber and Michael Frakes, Journal of Health Economics 25, Issue 2, 389-393.

Church et al, 2007. Effects of Different Doses of Physical Activity on Cardiorespiratory Fitness Among Sedentary, Overweight or Obese Postmenopausal Women with Elevated Blood Pressure, Journal of the American Medical Society. 297(19):2081-2091.

Courtemanche C., A. Carden. 2008. The Skinny on Big-Box Retailing: Wal-Mart, Warehouse Clubs and Obesity. Available http://ssrn.com/abstract=1263316

Cutler, David M., 2004. "Behavioral health interventions: what works and why," in Norman B. Anderson, Rodolfo A. Bulatao, and Barney Cohen, eds., Critical perspectives on racial and ethnic differences in health in late life, Washington, D.C. The National Academies Press.

Dutton G, Napolitano MA, Whiteley JA, Marucs BH. 2008. Is Physical Activity a Gateway Behavior for Diet? Findings from a Physical Activity Trial. Preventive Medicine. 46(3):21-221.

Cutler, David M. Edward L. Glaeser, and Jesse M. Shapiro 2003. Why Have Americans Become More Obese? Journal of Economics Perspectives 17(3), 93-118.

Finkelstein EA, Fiebelkorn IC, and Wang G. 2003. National Medical Spending Attributable to Overweight and Obesity: How Much and Who's Paying? Health Affairs - Web Exclusive. May 14.

Flegal KM, Carrol MD, Ogden CL, Johnson CL. Prevalence and trends in obesity among US adults, 19992000. JAMA. 2002;288:1723-27. 
Forsythe et al. 2007. Does Residential Density Increase Walking and Other Physical Activity? Urban Studies 44, 679-697.

Garret NA, Brasure M, Schmitz KH, Schulz MM, Huber MR. 2004. Physical Inactivity: Direct Cost to a Health Plan. American Journal of Preventive Medicine. 27(4):304-309.

Gruber, J., M. Frakes. 2006. Does falling smoking lead to rising obesity? Journal of Health Economics 25, 183-197.

Katzmarzky P.T., T. S. Church, S.N. Blair. 2004. Cardiorespiratory Fitness Attenuates the Effects of Metabolic Syndrome on All Cause and Cardiovascular Disease Mortality in Men, Archives of Internal Medicine.

Katzmarzky P.T., N. Gledhil, R.J. Shephard. 2000. The Economic Burden of Physical Inactivity in Canada, Canadian Medical Association Journal 163(11), 1435-1440.

Keeler E.B., W. G. Manning WG, J.P. Newhouse, E. M. Sloss and J. Wasserman. 1989. The External Costs of a Sedentary Life-style, American Journal of Public Health 79(8), 975-981.

Loh, Chung-Ping A. 2009. Physical Inactivity and Working Hour Inflexibility: Evidence from a U.S. Sample of Older Men. Review of Economics of the Househol., forthecoming.

Mullahy J. and S.A. Rober. 2008. No Time to Lose? Time Constraints and Physical Activity, NBER Working Paper 14513.

Murphy MH, Nevill AM, Murtagh EM, Holder RL. 2007. The Effect of Walking on fitness, fatness and resting blood pressure. Preventive Medicine. 44(5):377-385

Pelzman, S. 1975. The effects of automobile safety regulation, Journal of Political Economy 83, 677-725.

Philipson, Tomas. 2001. The world-wide growth in obesity: an economic research agenda, Health Economics 23(1), $1-7$.

Pratt M., C.A. Macera, G. Wang G. 2000. Higher Direct Medical Costs Associated with Physical Inactivity, The Physician and Sports Medicine 28(10).

Pratt M., C.A. Macera CA, J.F. Sallis, M. O’Donnell, L.D. Frank. 2004. Economic Interventions to Promote Physical Activity: Application of the SLOTH Model, American Journal of Preventive Medicine 27(3 Suppl), 136-145.

Rashad, Inas. 2006. Structural Estimation of Caloric Intake, Exercise, Smoking, and Obesity, Quarterly Review of Economics and Finance, 46(2), 268-283.

Rashad, Inas and Sara Markowitz. 2007. Incentives in Obesity and Health Insurance. NBER Working Paper No. W13113 Available at SSRN: http://ssrn.com/abstract=986963.

Romero-Corral A., V.K. Somers, J. Sierra-Johnson, R.J. Thomas, M.L. Collazo-Clavell, J. Korinek, T.G. Allison, J.A. Batsis, F.H. Sert-Kuniyoshi, F. Lopez-Jimenez . 2008. Accuracy of Body Mass Index in Diagnosing Obesity in the General Adult Population, International Journal of Obesity 32, 959966. 
Ruhm, Christopher. 2005. Healthy Living in Hard Times, Journal of Health Economics 24(2): 341-363.

Ruhm, Christopher. 2000. Are Recessions Good for Your Health? Quarterly Journal of Economics 115(2), 617-650.

Shinogle JA. 2008. Medical Expenditures Attributable to Inactivity, MIPAR Working paper.

Smith, Patricia K., Barry Bogin and David Bishai. 2005. Are time preference and body mass index associated?: Evidence from the National Longitudinal Survey of Youth, Economics \& Human Biology 3, Issue 2, , Socio-Economic correlates of overweight and obesity, 259-270.

Sturm R. The Effects of Obesity, Smoking and Drinking on Medical Problems and Costs. 2002. Health Affairs March/April 2002:21(2);245-253.

U.S. Dept. of Justice, Federal Bureau of Investigation. UNIFORM CRIME REPORTING PROGRAM DATA [UNITED STATES]: COUNTY-LEVEL DETAILED ARREST AND OFFENSE DATA, 2001-2005 [Computer file]. ICPSR03451-v4. Ann Arbor, MI: Inter-university Consortium for Political and Social Research [producer and distributor], 2006-01-16.

Yancey, Antronette K. , Jonathan E. Fielding, George R. Flores, James F. Sallis, William J. McCarthy, and Lester Breslow. 2007. Creating a Robust Public Health Infrastructure for Physical Activity Promotion, American Journal of Preventive Medicine 32(1), 68-78. 
Table 1: Descriptive Statistics

\begin{tabular}{|c|c|c|c|c|}
\hline Variable & Mean & Std. Dev. & Min & Max \\
\hline Any Leisure Time Activity in Past 30 Days & 0.696 & 0.460 & 0 & 1 \\
\hline Moderate or Vigorous PA & 0.124 & 0.330 & 0 & 1 \\
\hline Vigorous PA & 0.068 & 0.252 & 0 & 1 \\
\hline Age & 47.874 & 16.594 & 18 & 99 \\
\hline Age Squared & 2567.315 & 1710.999 & 324 & 9801 \\
\hline Male & 0.420 & 0.494 & 0 & 1 \\
\hline Hispanic & 0.068 & 0.252 & 0 & 1 \\
\hline White & 0.833 & 0.373 & 0 & 1 \\
\hline Black & 0.070 & 0.255 & 0 & 1 \\
\hline Asian & 0.023 & 0.149 & 0 & 1 \\
\hline Married & 0.574 & 0.494 & 0 & 1 \\
\hline High School Diploma & 0.284 & 0.451 & 0 & 1 \\
\hline Some College & 0.285 & 0.451 & 0 & 1 \\
\hline College Degree or More & 0.351 & 0.477 & 0 & 1 \\
\hline Income $<\$ 10 K$ & 0.048 & 0.214 & 0 & 1 \\
\hline Income $\$ 15 K<\$ 20 K$ & 0.053 & 0.224 & 0 & 1 \\
\hline Income $\$ 20 K<\$ 25 K$ & 0.074 & 0.261 & 0 & 1 \\
\hline Income $\$ 25 \mathrm{~K}<\$ 30 \mathrm{~K}$ & 0.097 & 0.297 & 0 & 1 \\
\hline Income $\$ 30 \mathrm{~K}<\$ 35 \mathrm{~K}$ & 0.144 & 0.351 & 0 & 1 \\
\hline Income $\$ 35 \mathrm{~K}<\$ 50 \mathrm{~K}$ & 0.182 & 0.386 & 0 & 1 \\
\hline Income $\$ 50 \mathrm{~K}<\$ 75 \mathrm{~K}$ & 0.180 & 0.384 & 0 & 1 \\
\hline Income $>\$ 75 \mathrm{~K}$ & 0.221 & 0.415 & 0 & 1 \\
\hline Unemployed & 0.043 & 0.203 & 0 & 1 \\
\hline Student or Homemaker & 0.097 & 0.295 & 0 & 1 \\
\hline Retired & 0.175 & 0.380 & 0 & 1 \\
\hline Insured & 0.882 & 0.323 & 0 & 1 \\
\hline Price of Bowling & 3.014 & 0.680 & 1 & 8.34 \\
\hline Price of Tennis Balls & 2.427 & 0.387 & 1.51 & 4.99 \\
\hline Price of Gas & 1.553 & 0.258 & 0.98 & 2.54 \\
\hline Bus Fare & 1.125 & 0.498 & 0.25 & 3.35 \\
\hline Unemployment Rate & 5.233 & 1.597 & 1.6 & 15.9 \\
\hline Violent Crime Rate & 4.473 & 3.329 & 0 & 48.31 \\
\hline Property Crime Rate & 38.248 & 16.113 & 0 & 217.37 \\
\hline Number of Gyms Per Capita & 0.103 & 0.047 & 0 & 0.48 \\
\hline Number of Parks Per Capita & 0.002 & 0.007 & 0 & 0.14 \\
\hline Number of Other Rec Areas Per Capita & 0.141 & 0.114 & 0 & 2.72 \\
\hline Cigarette Tax & 0.690 & 0.474 & 0.025 & 2.05 \\
\hline Beer Tax & 0.214 & 0.154 & 0.02 & 0.92 \\
\hline Overweight & 0.350 & 0.477 & 0 & 1 \\
\hline
\end{tabular}


Obese

Flu Shot

Number of Observations $=383,950$
$0.223 \quad 0.416$

0.327

0.469

0

0

1

1 
Table 2: Participation in Any Exercise

Model 1: Basic Demographics

\section{Model 2: Add Model 3: $\quad$ Model 4: $\quad$ Model 5: Area Variables \\ Add Weight \\ Add Flu \\ Shots \\ Add Months}

\begin{tabular}{|c|c|c|c|c|c|}
\hline Age & $\begin{array}{l}-0.00274 \\
(0)\end{array}$ & $\begin{array}{l}-0.00244 \\
(0)\end{array}$ & $\begin{array}{l}-0.00113 \\
(4.73 e-07)\end{array}$ & $\begin{array}{l}-0.00105 \\
(2.90 e-06)\end{array}$ & $\begin{array}{l}-0.00104 \\
(3.07 e-06)\end{array}$ \\
\hline Age Squared & $\begin{array}{l}-3.03 e-06 \\
(0.0303)\end{array}$ & $\begin{array}{l}-5.74 e-06 \\
(0.0119)\end{array}$ & $\begin{array}{l}-1.82 \mathrm{e}-05 \\
(0)\end{array}$ & $\begin{array}{l}-2.01 \mathrm{e}-05 \\
(0)\end{array}$ & $\begin{array}{l}-2.03 e-05 \\
(0)\end{array}$ \\
\hline Male & $\begin{array}{l}0.0219 \\
(0)\end{array}$ & $\begin{array}{l}0.0228 \\
(0)\end{array}$ & $\begin{array}{l}0.0249 \\
(0)\end{array}$ & $\begin{array}{l}0.0252 \\
(0)\end{array}$ & $\begin{array}{l}0.0257 \\
(0)\end{array}$ \\
\hline Hispanic & $\begin{array}{l}-0.0389 \\
(0)\end{array}$ & $\begin{array}{l}-0.0399 \\
(0)\end{array}$ & $\begin{array}{l}-0.0404 \\
(0)\end{array}$ & $\begin{array}{l}-0.0406 \\
(0)\end{array}$ & $\begin{array}{l}-0.0408 \\
(0)\end{array}$ \\
\hline White & $\begin{array}{l}0.0188 \\
(0)\end{array}$ & $\begin{array}{l}0.0137 \\
(7.48 e-08)\end{array}$ & $\begin{array}{l}0.0112 \\
(1.07 e-05)\end{array}$ & $\begin{array}{l}0.0113 \\
(9.60 e-06)\end{array}$ & $\begin{array}{l}0.0117 \\
(3.98 e-06)\end{array}$ \\
\hline Black & $\begin{array}{l}-0.0289 \\
(0)\end{array}$ & $\begin{array}{l}-0.0346 \\
(0)\end{array}$ & $\begin{array}{l}-0.0294 \\
(0)\end{array}$ & $\begin{array}{l}-0.0290 \\
(0)\end{array}$ & $\begin{array}{l}-0.0288 \\
(0)\end{array}$ \\
\hline Asian & $\begin{array}{l}-0.0540 \\
(0)\end{array}$ & $\begin{array}{l}-0.0710 \\
(0)\end{array}$ & $\begin{array}{l}-0.0816 \\
(0)\end{array}$ & $\begin{array}{l}-0.0820 \\
(0)\end{array}$ & $\begin{array}{l}-0.0811 \\
(0)\end{array}$ \\
\hline Married & $\begin{array}{l}-0.0129 \\
(0)\end{array}$ & $\begin{array}{l}-0.0147 \\
(0)\end{array}$ & $\begin{array}{l}-0.0138 \\
(0)\end{array}$ & $\begin{array}{l}-0.0139 \\
(0)\end{array}$ & $\begin{array}{l}-0.0139 \\
(0)\end{array}$ \\
\hline High School Diploma & $\begin{array}{l}0.0735 \\
(0)\end{array}$ & $\begin{array}{l}0.0785 \\
(0)\end{array}$ & $\begin{array}{l}0.0770 \\
(0)\end{array}$ & $\begin{array}{l}0.0769 \\
(0)\end{array}$ & $\begin{array}{l}0.0767 \\
(0)\end{array}$ \\
\hline Some College & $\begin{array}{l}0.134 \\
(0)\end{array}$ & $\begin{array}{l}0.137 \\
(0)\end{array}$ & $\begin{array}{l}0.135 \\
(0)\end{array}$ & $\begin{array}{l}0.135 \\
(0)\end{array}$ & $\begin{array}{l}0.134 \\
(0)\end{array}$ \\
\hline College Degree or More & $\begin{array}{l}0.180 \\
(0)\end{array}$ & $\begin{array}{l}0.182 \\
(0)\end{array}$ & $\begin{array}{l}0.176 \\
(0)\end{array}$ & $\begin{array}{l}0.176 \\
(0)\end{array}$ & $\begin{array}{l}0.175 \\
(0)\end{array}$ \\
\hline Income $<\$ 10 \mathrm{~K}$ & $\begin{array}{l}-0.198 \\
(0)\end{array}$ & $\begin{array}{l}-0.191 \\
(0)\end{array}$ & $\begin{array}{l}-0.183 \\
(0)\end{array}$ & $\begin{array}{l}-0.183 \\
(0)\end{array}$ & $\begin{array}{l}-0.182 \\
(0)\end{array}$ \\
\hline Income $\$ 15 K<\$ 20 K$ & $\begin{array}{l}-0.178 \\
(0)\end{array}$ & $\begin{array}{l}-0.172 \\
(0)\end{array}$ & $\begin{array}{l}-0.165 \\
(0)\end{array}$ & $\begin{array}{l}-0.165 \\
(0)\end{array}$ & $\begin{array}{l}-0.164 \\
(0)\end{array}$ \\
\hline Income $\$ 20 K<\$ 25 K$ & $\begin{array}{l}-0.151 \\
(0)\end{array}$ & $\begin{array}{l}-0.147 \\
(0)\end{array}$ & $\begin{array}{l}-0.141 \\
(0)\end{array}$ & $\begin{array}{l}-0.141 \\
(0)\end{array}$ & $\begin{array}{l}-0.141 \\
(0)\end{array}$ \\
\hline Income $\$ 25 \mathrm{~K}<\$ 30 \mathrm{~K}$ & $\begin{array}{l}-0.124 \\
(0)\end{array}$ & $\begin{array}{l}-0.122 \\
(0)\end{array}$ & $\begin{array}{l}-0.117 \\
(0)\end{array}$ & $\begin{array}{l}-0.117 \\
(0)\end{array}$ & $\begin{array}{l}-0.117 \\
(0)\end{array}$ \\
\hline Income $\$ 30 K<\$ 35 K$ & $\begin{array}{l}-0.0919 \\
(0)\end{array}$ & $\begin{array}{l}-0.0891 \\
(0)\end{array}$ & $\begin{array}{l}-0.0851 \\
(0)\end{array}$ & $\begin{array}{l}-0.0849 \\
(0)\end{array}$ & $\begin{array}{l}-0.0848 \\
(0)\end{array}$ \\
\hline Income $\$ 35 \mathrm{~K}<\$ 50 \mathrm{~K}$ & $\begin{array}{l}-0.0623 \\
(0)\end{array}$ & $\begin{array}{l}-0.0596 \\
(0)\end{array}$ & $\begin{array}{l}-0.0559 \\
(0)\end{array}$ & $\begin{array}{l}-0.0557 \\
(0)\end{array}$ & $\begin{array}{l}-0.0557 \\
(0)\end{array}$ \\
\hline Income $\$ 50 \mathrm{~K}<\$ 75 \mathrm{~K}$ & $\begin{array}{l}-0.0349 \\
(0)\end{array}$ & $\begin{array}{l}-0.0346 \\
(0)\end{array}$ & $\begin{array}{l}-0.0320 \\
(0)\end{array}$ & $\begin{array}{l}-0.0318 \\
(0)\end{array}$ & $\begin{array}{l}-0.0317 \\
(0)\end{array}$ \\
\hline Unemployed & $\begin{array}{l}0.00894 \\
(4.31 \mathrm{e}-06)\end{array}$ & $\begin{array}{l}0.0141 \\
(4.73 e-06)\end{array}$ & $\begin{array}{l}0.0148 \\
(1.50 e-06)\end{array}$ & $\begin{array}{l}0.0151 \\
(9.49 e-07)\end{array}$ & $\begin{array}{l}0.0151 \\
(8.42 \mathrm{e}-07)\end{array}$ \\
\hline Student or Homemaker & 0.0451 & 0.0393 & 0.0369 & 0.0372 & 0.0375 \\
\hline
\end{tabular}




\begin{tabular}{|c|c|c|c|c|c|}
\hline & (0) & (0) & (0) & (0) & (0) \\
\hline \multirow[t]{2}{*}{ Retired } & 0.0731 & 0.0676 & 0.0673 & 0.0662 & 0.0660 \\
\hline & $(0)$ & (0) & $(0)$ & (0) & (0) \\
\hline \multirow[t]{2}{*}{ Insured } & 0.0131 & 0.0119 & 0.0140 & 0.0126 & 0.0130 \\
\hline & (0) & (4.93e-09) & (0) & $(5.88 \mathrm{e}-10)$ & $(1.95 e-10)$ \\
\hline \multirow[t]{2}{*}{ Price of Bowling } & & -0.00424 & -0.00443 & -0.00425 & -0.00268 \\
\hline & & $(0.125)$ & $(0.108)$ & $(0.122)$ & $(0.329)$ \\
\hline \multirow[t]{2}{*}{ Price of Tennis Balls } & & -0.000894 & -0.00144 & -0.00138 & -0.000140 \\
\hline & & $(0.714)$ & $(0.555)$ & $(0.571)$ & $(0.954)$ \\
\hline \multirow[t]{2}{*}{ Price of Gas } & & -0.0120 & -0.0113 & -0.0108 & -0.0106 \\
\hline & & $(0.0250)$ & $(0.0343)$ & $(0.0428)$ & (0.0459) \\
\hline \multirow[t]{2}{*}{ Bus Fare } & & 0.0107 & 0.0113 & 0.0107 & 0.00668 \\
\hline & & $(0.00217)$ & $(0.00117)$ & $(0.00213)$ & $(0.0545)$ \\
\hline \multirow[t]{2}{*}{ Unemployment Rate } & & -0.00327 & -0.00295 & -0.00295 & -0.00301 \\
\hline & & $(2.60 \mathrm{e}-07)$ & (3.09e-06) & $(3.18 \mathrm{e}-06)$ & $(1.91 e-06)$ \\
\hline \multirow[t]{2}{*}{ Violent Crime Rate } & & -0.000491 & -0.000569 & -0.000565 & -0.000550 \\
\hline & & $(0.157)$ & $(0.0998)$ & $(0.102)$ & $(0.111)$ \\
\hline \multirow[t]{2}{*}{ Property Crime Rate } & & $-3.07 e-05$ & $-2.67 e-05$ & $-3.04 e-05$ & $-3.91 e-05$ \\
\hline & & $(0.641)$ & $(0.684)$ & $(0.643)$ & $(0.550)$ \\
\hline \multirow[t]{2}{*}{ Number of Gyms Per Capita } & & 0.0871 & 0.0748 & 0.0741 & 0.0715 \\
\hline & & $(2.47 e-08)$ & $(1.58 \mathrm{e}-06)$ & $(1.96 \mathrm{e}-06)$ & $(4.22 \mathrm{e}-06)$ \\
\hline \multirow[t]{2}{*}{ Number of Parks Per Capita } & & 0.247 & 0.225 & 0.226 & 0.218 \\
\hline & & (0.00599) & $(0.0123)$ & $(0.0117)$ & $(0.0149)$ \\
\hline \multirow{2}{*}{$\begin{array}{l}\text { Number of Other Rec Areas Per } \\
\text { Capita }\end{array}$} & & 0.0257 & 0.0233 & 0.0239 & 0.0246 \\
\hline & & (8.59e-05) & $(0.000350)$ & $(0.000245)$ & $(0.000158)$ \\
\hline \multirow[t]{2}{*}{ Cigarette Tax } & & 0.00106 & 0.00101 & 0.00159 & -0.00222 \\
\hline & & $(0.802)$ & $(0.809)$ & $(0.705)$ & $(0.597)$ \\
\hline \multirow[t]{2}{*}{ Beer Tax } & & 0.0187 & 0.0178 & 0.0181 & 0.00772 \\
\hline & & $(0.758)$ & $(0.769)$ & $(0.765)$ & $(0.898)$ \\
\hline \multirow[t]{2}{*}{ Overweight } & & & -0.00644 & -0.00665 & -0.00667 \\
\hline & & & $(5.72 e-06)$ & $(2.81 e-06)$ & $(2.51 \mathrm{e}-06)$ \\
\hline \multirow[t]{2}{*}{ Obese } & & & -0.0732 & -0.0737 & -0.0738 \\
\hline & & & (0) & (0) & $(0)$ \\
\hline \multirow[t]{2}{*}{ Flu Shot } & & & & 0.0142 & 0.0138 \\
\hline & & & & (0) & $(0)$ \\
\hline Observations & 1057541 & 383950 & 383950 & 383950 & 383950 \\
\hline R-squared & 0.323 & 0.339 & 0.342 & 0.343 & 0.345 \\
\hline
\end{tabular}


Table 3: Participation in Any Exercise - Female

Model 1: Basic

Demographics

\section{Model 2: Add Model 3: $\quad$ Model 4: $\quad$ Model 5: Area Variables Add Add Flu Add Weight Shots Months}

\begin{tabular}{|c|c|c|c|c|c|}
\hline Age & $\begin{array}{l}-0.000779 \\
(1.88 e-05)\end{array}$ & $\begin{array}{l}-0.000361 \\
(0.224)\end{array}$ & $\begin{array}{l}0.00138 \\
(3.79 e-06)\end{array}$ & $\begin{array}{l}0.00140 \\
(2.72 \mathrm{e}-06)\end{array}$ & $\begin{array}{l}0.00139 \\
(3.10 \mathrm{e}-06)\end{array}$ \\
\hline Age Squared & $\begin{array}{l}-2.13 e-05 \\
\text { (0) }\end{array}$ & $\begin{array}{l}-2.58 \mathrm{e}-05 \\
(0)\end{array}$ & $\begin{array}{l}-4.22 \mathrm{e}-05 \\
(0)\end{array}$ & $\begin{array}{l}-4.33 e-05 \\
(0)\end{array}$ & $\begin{array}{l}-4.32 e-05 \\
(0)\end{array}$ \\
\hline Hispanic & $\begin{array}{l}-0.0464 \\
(0)\end{array}$ & $\begin{array}{l}-0.0462 \\
(0)\end{array}$ & $\begin{array}{l}-0.0465 \\
(0)\end{array}$ & $\begin{array}{l}-0.0467 \\
(0)\end{array}$ & $\begin{array}{l}-0.0463 \\
(0)\end{array}$ \\
\hline White & $\begin{array}{l}0.0239 \\
(0)\end{array}$ & $\begin{array}{l}0.0180 \\
(3.20 \mathrm{e}-07)\end{array}$ & $\begin{array}{l}0.0147 \\
(2.80 \mathrm{e}-05)\end{array}$ & $\begin{array}{l}0.0146 \\
(3.13 e-05)\end{array}$ & $\begin{array}{l}0.0154 \\
(1.12 \mathrm{e}-05)\end{array}$ \\
\hline Black & $\begin{array}{l}-0.0381 \\
(0)\end{array}$ & $\begin{array}{l}-0.0461 \\
(0)\end{array}$ & $\begin{array}{l}-0.0371 \\
(0)\end{array}$ & $\begin{array}{l}-0.0367 \\
(0)\end{array}$ & $\begin{array}{l}-0.0361 \\
(0)\end{array}$ \\
\hline Asian & $\begin{array}{l}-0.0551 \\
(0)\end{array}$ & $\begin{array}{l}-0.0801 \\
(0)\end{array}$ & $\begin{array}{l}-0.0935 \\
(0)\end{array}$ & $\begin{array}{l}-0.0940 \\
(0)\end{array}$ & $\begin{array}{l}-0.0924 \\
(0)\end{array}$ \\
\hline Married & $\begin{array}{l}-0.0183 \\
(0)\end{array}$ & $\begin{array}{l}-0.0201 \\
(0)\end{array}$ & $\begin{array}{l}-0.0196 \\
(0)\end{array}$ & $\begin{array}{l}-0.0196 \\
(0)\end{array}$ & $\begin{array}{l}-0.0195 \\
(0)\end{array}$ \\
\hline High School Diploma & $\begin{array}{l}0.0729 \\
(0)\end{array}$ & $\begin{array}{l}0.0806 \\
(0)\end{array}$ & $\begin{array}{l}0.0774 \\
(0)\end{array}$ & $\begin{array}{l}0.0773 \\
(0)\end{array}$ & $\begin{array}{l}0.0770 \\
(0)\end{array}$ \\
\hline Some College & $\begin{array}{l}0.134 \\
(0)\end{array}$ & $\begin{array}{l}0.140 \\
(0)\end{array}$ & $\begin{array}{l}0.136 \\
(0)\end{array}$ & $\begin{array}{l}0.136 \\
(0)\end{array}$ & $\begin{array}{l}0.136 \\
(0)\end{array}$ \\
\hline College Degree or More & $\begin{array}{l}0.181 \\
(0)\end{array}$ & $\begin{array}{l}0.188 \\
(0)\end{array}$ & $\begin{array}{l}0.180 \\
(0)\end{array}$ & $\begin{array}{l}0.179 \\
(0)\end{array}$ & $\begin{array}{l}0.179 \\
(0)\end{array}$ \\
\hline Income $<\$ 10 K$ & $\begin{array}{l}-0.202 \\
(0)\end{array}$ & $\begin{array}{l}-0.192 \\
(0)\end{array}$ & $\begin{array}{l}-0.178 \\
(0)\end{array}$ & $\begin{array}{l}-0.178 \\
(0)\end{array}$ & $\begin{array}{l}-0.176 \\
(0)\end{array}$ \\
\hline Income $\$ 15 K<\$ 20 K$ & $\begin{array}{l}-0.179 \\
(0)\end{array}$ & $\begin{array}{l}-0.171 \\
(0)\end{array}$ & $\begin{array}{l}-0.158 \\
(0)\end{array}$ & $\begin{array}{l}-0.157 \\
(0)\end{array}$ & $\begin{array}{l}-0.157 \\
(0)\end{array}$ \\
\hline Income $\$ 20 K<\$ 25 K$ & $\begin{array}{l}-0.151 \\
(0)\end{array}$ & $\begin{array}{l}-0.147 \\
(0)\end{array}$ & $\begin{array}{l}-0.136 \\
(0)\end{array}$ & $\begin{array}{l}-0.136 \\
(0)\end{array}$ & $\begin{array}{l}-0.135 \\
(0)\end{array}$ \\
\hline Income $\$ 25 \mathrm{~K}<\$ 30 \mathrm{~K}$ & $\begin{array}{l}-0.125 \\
(0)\end{array}$ & $\begin{array}{l}-0.120 \\
(0)\end{array}$ & $\begin{array}{l}-0.110 \\
(0)\end{array}$ & $\begin{array}{l}-0.110 \\
(0)\end{array}$ & $\begin{array}{l}-0.109 \\
(0)\end{array}$ \\
\hline Income $\$ 30 K<\$ 35 K$ & $\begin{array}{l}-0.0896 \\
(0)\end{array}$ & $\begin{array}{l}-0.0850 \\
(0)\end{array}$ & $\begin{array}{l}-0.0762 \\
(0)\end{array}$ & $\begin{array}{l}-0.0760 \\
(0)\end{array}$ & $\begin{array}{l}-0.0757 \\
(0)\end{array}$ \\
\hline Income $\$ 35 \mathrm{~K}<\$ 50 \mathrm{~K}$ & $\begin{array}{l}-0.0591 \\
(0)\end{array}$ & $\begin{array}{l}-0.0572 \\
(0)\end{array}$ & $\begin{array}{l}-0.0495 \\
(0)\end{array}$ & $\begin{array}{l}-0.0493 \\
(0)\end{array}$ & $\begin{array}{l}-0.0490 \\
(0)\end{array}$ \\
\hline Income $\$ 50 \mathrm{~K}<\$ 75 \mathrm{~K}$ & $\begin{array}{l}-0.0335 \\
(0)\end{array}$ & $\begin{array}{l}-0.0346 \\
(0)\end{array}$ & $\begin{array}{l}-0.0293 \\
(0)\end{array}$ & $\begin{array}{l}-0.0292 \\
(0)\end{array}$ & $\begin{array}{l}-0.0288 \\
(0)\end{array}$ \\
\hline Unemployed & $\begin{array}{l}0.00647 \\
(0.0117)\end{array}$ & $\begin{array}{l}0.0126 \\
(0.00229)\end{array}$ & $\begin{array}{l}0.0132 \\
(0.00140)\end{array}$ & $\begin{array}{l}0.0134 \\
(0.00116)\end{array}$ & $\begin{array}{l}0.0127 \\
(0.00194)\end{array}$ \\
\hline Student or Homemaker & $\begin{array}{l}0.0458 \\
(0)\end{array}$ & $\begin{array}{l}0.0395 \\
(0)\end{array}$ & $\begin{array}{l}0.0368 \\
(0)\end{array}$ & $\begin{array}{l}0.0371 \\
(0)\end{array}$ & $\begin{array}{l}0.0372 \\
(0)\end{array}$ \\
\hline
\end{tabular}




\begin{tabular}{|c|c|c|c|c|c|}
\hline Retired & $\begin{array}{l}0.0751 \\
(0)\end{array}$ & $\begin{array}{l}0.0698 \\
(0)\end{array}$ & $\begin{array}{l}0.0691 \\
(0)\end{array}$ & $\begin{array}{l}0.0685 \\
(0)\end{array}$ & $\begin{array}{l}0.0681 \\
(0)\end{array}$ \\
\hline Insured & $\begin{array}{l}0.00558 \\
(0.000896)\end{array}$ & $\begin{array}{l}0.00569 \\
(0.0431)\end{array}$ & $\begin{array}{l}0.00797 \\
(0.00449)\end{array}$ & $\begin{array}{l}0.00690 \\
(0.0140)\end{array}$ & $\begin{array}{l}0.00712 \\
(0.0111)\end{array}$ \\
\hline Price of Bowling & & $\begin{array}{l}-0.00735 \\
(0.0484)\end{array}$ & $\begin{array}{l}-0.00730 \\
(0.0488)\end{array}$ & $\begin{array}{l}-0.00713 \\
(0.0546)\end{array}$ & $\begin{array}{l}-0.00519 \\
(0.161)\end{array}$ \\
\hline Price of Tennis Balls & & $\begin{array}{l}-0.00159 \\
(0.629)\end{array}$ & $\begin{array}{l}-0.00216 \\
(0.509)\end{array}$ & $\begin{array}{l}-0.00211 \\
(0.521)\end{array}$ & $\begin{array}{l}-0.00107 \\
(0.744)\end{array}$ \\
\hline Price of Gas & & $\begin{array}{l}-0.0103 \\
(0.152)\end{array}$ & $\begin{array}{l}-0.00898 \\
(0.211)\end{array}$ & $\begin{array}{l}-0.00853 \\
(0.235)\end{array}$ & $\begin{array}{l}-0.00798 \\
(0.265)\end{array}$ \\
\hline Bus Fare & & $\begin{array}{l}0.0135 \\
(0.00406)\end{array}$ & $\begin{array}{l}0.0139 \\
(0.00295)\end{array}$ & $\begin{array}{l}0.0134 \\
(0.00422)\end{array}$ & $\begin{array}{l}0.00852 \\
(0.0689)\end{array}$ \\
\hline Unemployment Rate & & $\begin{array}{l}-0.00378 \\
(1.01 \mathrm{e}-05)\end{array}$ & $\begin{array}{l}-0.00337 \\
(7.80 \mathrm{e}-05)\end{array}$ & $\begin{array}{l}-0.00337 \\
(7.60 \mathrm{e}-05)\end{array}$ & $\begin{array}{l}-0.00349 \\
(4.01 \mathrm{e}-05)\end{array}$ \\
\hline Violent Crime Rate & & $\begin{array}{l}-0.000295 \\
(0.524)\end{array}$ & $\begin{array}{l}-0.000404 \\
(0.382)\end{array}$ & $\begin{array}{l}-0.000401 \\
(0.385)\end{array}$ & $\begin{array}{l}-0.000352 \\
(0.444)\end{array}$ \\
\hline Property Crime Rate & & $\begin{array}{l}-9.75 e-05 \\
(0.270)\end{array}$ & $\begin{array}{l}-8.49 e-05 \\
(0.334)\end{array}$ & $\begin{array}{l}-8.78 \mathrm{e}-05 \\
(0.318)\end{array}$ & $\begin{array}{l}-0.000102 \\
(0.245)\end{array}$ \\
\hline Number of Gyms Per Capita & & $\begin{array}{l}0.0566 \\
(0.00768)\end{array}$ & $\begin{array}{l}0.0406 \\
(0.0552)\end{array}$ & $\begin{array}{l}0.0397 \\
(0.0603)\end{array}$ & $\begin{array}{l}0.0354 \\
(0.0933)\end{array}$ \\
\hline Number of Parks Per Capita & & $\begin{array}{l}0.261 \\
(0.0321)\end{array}$ & $\begin{array}{l}0.237 \\
(0.0510)\end{array}$ & $\begin{array}{l}0.238 \\
(0.0501)\end{array}$ & $\begin{array}{l}0.231 \\
(0.0567)\end{array}$ \\
\hline $\begin{array}{l}\text { Number of Other Rec Areas Per } \\
\text { Capita }\end{array}$ & & 0.0322 & 0.0277 & 0.0280 & 0.0292 \\
\hline & & (0.000301) & $(0.00182)$ & $(0.00158)$ & $(0.000983)$ \\
\hline Cigarette Tax & & $\begin{array}{l}0.00209 \\
(0.713)\end{array}$ & $\begin{array}{l}0.00210 \\
(0.711)\end{array}$ & $\begin{array}{l}0.00252 \\
(0.656)\end{array}$ & $\begin{array}{l}-0.00179 \\
(0.751)\end{array}$ \\
\hline Beer Tax & & $\begin{array}{l}0.115 \\
(0.166)\end{array}$ & $\begin{array}{l}0.111 \\
(0.179)\end{array}$ & $\begin{array}{l}0.111 \\
(0.179)\end{array}$ & $\begin{array}{l}0.0981 \\
(0.234)\end{array}$ \\
\hline Overweight & & & $\begin{array}{l}-0.0143 \\
(0)\end{array}$ & $\begin{array}{l}-0.0145 \\
(0)\end{array}$ & $\begin{array}{l}-0.0147 \\
(0)\end{array}$ \\
\hline Obese & & & $\begin{array}{l}-0.0916 \\
(0)\end{array}$ & $\begin{array}{l}-0.0921 \\
(0)\end{array}$ & $\begin{array}{l}-0.0923 \\
(0)\end{array}$ \\
\hline Flu Shot & & & & $\begin{array}{l}0.0111 \\
(4.05 e-09)\end{array}$ & $\begin{array}{l}0.0107 \\
(1.48 \mathrm{e}-08)\end{array}$ \\
\hline & 621267 & 222823 & 222823 & 222823 & 222823 \\
\hline R-squared & 0.304 & 0.319 & 0.325 & 0.325 & 0.329 \\
\hline
\end{tabular}

$p$-values in parentheses 


\section{Table 4: Participation in Any Exercise - Male}

Model 1: Basic

Demographics

\begin{tabular}{|c|c|}
\hline Age & $\begin{array}{l}-0.00554 \\
\text { (0) }\end{array}$ \\
\hline Age Squared & $\begin{array}{l}2.35 e-05 \\
\text { (0) }\end{array}$ \\
\hline Hispanic & $\begin{array}{l}-0.0279 \\
(0)\end{array}$ \\
\hline White & $\begin{array}{l}0.0129 \\
(3.30 \mathrm{e}-08)\end{array}$ \\
\hline Black & $\begin{array}{l}-0.00737 \\
(0.0206)\end{array}$ \\
\hline Asian & $\begin{array}{l}-0.0538 \\
(0)\end{array}$ \\
\hline Married & $\begin{array}{l}-0.00586 \\
(2.96 e-06)\end{array}$ \\
\hline High School Diploma & $\begin{array}{l}0.0747 \\
(0)\end{array}$ \\
\hline Some College & $\begin{array}{l}0.133 \\
(0)\end{array}$ \\
\hline College Degree or More & $\begin{array}{l}0.179 \\
(0)\end{array}$ \\
\hline Income $<\$ 10 \mathrm{~K}$ & $\begin{array}{l}-0.186 \\
(0)\end{array}$ \\
\hline Income $\$ 15 K<\$ 20 K$ & $\begin{array}{l}-0.175 \\
(0)\end{array}$ \\
\hline Income $\$ 20 K<\$ 25 K$ & $\begin{array}{l}-0.153 \\
(0)\end{array}$ \\
\hline Income $\$ 25 \mathrm{~K}<\$ 30 \mathrm{~K}$ & $\begin{array}{l}-0.124 \\
(0)\end{array}$ \\
\hline Income $\$ 30 \mathrm{~K}<\$ 35 \mathrm{~K}$ & $\begin{array}{l}-0.0965 \\
(0)\end{array}$ \\
\hline Income $\$ 35 \mathrm{~K}<\$ 50 \mathrm{~K}$ & $\begin{array}{l}-0.0673 \\
(0)\end{array}$ \\
\hline Income $\$ 50 \mathrm{~K}<\$ 75 \mathrm{~K}$ & $\begin{array}{l}-0.0371 \\
(0)\end{array}$ \\
\hline Unemployed & $\begin{array}{l}0.0139 \\
(2.93 e-06)\end{array}$ \\
\hline Student or Homemaker & $\begin{array}{l}0.0541 \\
(0)\end{array}$ \\
\hline Retired & 0.0695 \\
\hline
\end{tabular}

(0)

\section{Model 2: $\quad$ Model 3: $\quad$ Model 4: $\quad$ Model 5: Add Area Add Add Flu Add Variables Weight Shots Months}

$\begin{array}{llll}-0.00538 & -0.00472 & -0.00454 & -0.00451 \\ (0) & (0) & (0) & (0) \\ 2.35 \mathrm{e}-05 & 1.68 \mathrm{e}-05 & 1.36 \mathrm{e}-05 & 1.32 \mathrm{e}-05 \\ (0) & (1.95 \mathrm{e}-06) & (0.000124) & (0.000193) \\ -0.0310 & -0.0318 & -0.0321 & -0.0326 \\ (0) & (0) & (0) & (0) \\ 0.00895 & 0.00729 & 0.00762 & 0.00779 \\ (0.0143) & (0.0458) & (0.0368) & (0.0326) \\ -0.0105 & -0.00966 & -0.00934 & -0.00960 \\ (0.0442) & (0.0635) & (0.0727) & (0.0647) \\ -0.0613 & -0.0671 & -0.0671 & -0.0669 \\ (0) & (0) & (0) & (0) \\ -0.00771 & -0.00671 & -0.00709 & -0.00694 \\ (0.000130) & (0.000870) & (0.000437) & (0.000562) \\ 0.0760 & 0.0756 & 0.0753 & 0.0752 \\ (0) & (0) & (0) & (0)\end{array}$

$\begin{array}{llll}(0) & (0) & (0) & \text { (0) }\end{array}$

$\begin{array}{llll}0.132 & 0.132 & 0.131 & 0.131\end{array}$

(0) $\quad$ (0)

0.174

(0)

0.171

(0)

(0)

$0.170 \quad 0.169$

$\begin{array}{llll}-0.187 & -0.184 & -0.184 & -0.183\end{array}$

(0)

(0)

$-0.171$

(0)

(0)

$\begin{array}{llll}-0.173 & -0.171 & -0.171 & -0.171\end{array}$

$\begin{array}{llll}(0) & (0) & \text { (0) } & \text { (0) }\end{array}$

$\begin{array}{llll}-0.147 & -0.146 & -0.145 & -0.145\end{array}$

$\begin{array}{llll}(0) & (0) & \text { (0) }\end{array}$

$\begin{array}{llll}-0.126 & -0.125 & -0.125 & -0.125\end{array}$

$\begin{array}{llll}(0) & (0) & \text { (0) } & \text { (0) }\end{array}$

$\begin{array}{llll}-0.0967 & -0.0957 & -0.0955 & -0.0954 \\ (0) & (0) & (0)\end{array}$

$\begin{array}{llll}(0) & (0) & (0) & \text { (0) }\end{array}$

$\begin{array}{llll}-0.0641 & -0.0631 & -0.0628 & -0.0630\end{array}$

$\begin{array}{llll}(0) & (0) & (0) & \text { (0) }\end{array}$

$\begin{array}{llll}-0.0353 & -0.0343 & -0.0341 & -0.0342\end{array}$

$\begin{array}{llll}(0) & (0) & \text { (0) } & \text { (0) }\end{array}$

$\begin{array}{llll}0.0173 & 0.0184 & 0.0187 & 0.0194\end{array}$ $\begin{array}{llll}(0.000183) \quad(6.56 \mathrm{e}-05) \quad(4.80 \mathrm{e}-05) \quad(2.47 \mathrm{e}-05) & 0.0510 & 0.0521\end{array}$ $\begin{array}{llll}0.0516 & 0.0513 & 0.0510 & 0.0521\end{array}$

$\begin{array}{llll}(0) & (0) & (0) & \text { (0) }\end{array}$

$\begin{array}{llll}0.0625 & 0.0629 & 0.0615 & 0.0614\end{array}$

(0)

(0)

(0)

(0) 


\begin{tabular}{|c|c|c|c|c|c|}
\hline Insured & $\begin{array}{l}0.0240 \\
(0)\end{array}$ & $\begin{array}{l}0.0208 \\
(0)\end{array}$ & $\begin{array}{l}0.0216 \\
(0)\end{array}$ & $\begin{array}{l}0.0200 \\
(0)\end{array}$ & $\begin{array}{l}0.0204 \\
(0)\end{array}$ \\
\hline Price of Bowling & & $\begin{array}{l}7.94 \mathrm{e}-05 \\
(0.984)\end{array}$ & $\begin{array}{l}-0.000114 \\
(0.978)\end{array}$ & $\begin{array}{l}3.06 \mathrm{e}-05 \\
(0.994)\end{array}$ & $\begin{array}{l}0.00112 \\
(0.784)\end{array}$ \\
\hline Price of Tennis Balls & & $\begin{array}{l}0.000338 \\
(0.926)\end{array}$ & $\begin{array}{l}-0.000159 \\
(0.965)\end{array}$ & $\begin{array}{l}-0.000110 \\
(0.976)\end{array}$ & $\begin{array}{l}0.00123 \\
(0.733)\end{array}$ \\
\hline Price of Gas & & $\begin{array}{l}-0.0140 \\
(0.0773)\end{array}$ & $\begin{array}{l}-0.0138 \\
(0.0811)\end{array}$ & $\begin{array}{l}-0.0133 \\
(0.0915)\end{array}$ & $\begin{array}{l}-0.0135 \\
(0.0866)\end{array}$ \\
\hline Bus Fare & & $\begin{array}{l}0.00681 \\
(0.186)\end{array}$ & $\begin{array}{l}0.00736 \\
(0.153)\end{array}$ & $\begin{array}{l}0.00670 \\
(0.193)\end{array}$ & $\begin{array}{l}0.00387 \\
(0.452)\end{array}$ \\
\hline Unemployment Rate & & $\begin{array}{l}-0.00229 \\
(0.0149)\end{array}$ & $\begin{array}{l}-0.00214 \\
(0.0225)\end{array}$ & $\begin{array}{l}-0.00212 \\
(0.0235)\end{array}$ & $\begin{array}{l}-0.00213 \\
(0.0231)\end{array}$ \\
\hline Violent Crime Rate & & $\begin{array}{l}-0.000736 \\
(0.156)\end{array}$ & $\begin{array}{l}-0.000761 \\
(0.142)\end{array}$ & $\begin{array}{l}-0.000756 \\
(0.145)\end{array}$ & $\begin{array}{l}-0.000771 \\
(0.137)\end{array}$ \\
\hline Property Crime Rate & & $\begin{array}{l}6.24 \mathrm{e}-05 \\
(0.524)\end{array}$ & $\begin{array}{l}5.97 \mathrm{e}-05 \\
(0.541)\end{array}$ & $\begin{array}{l}5.57 \mathrm{e}-05 \\
(0.569)\end{array}$ & $\begin{array}{l}5.26 \mathrm{e}-05 \\
(0.590)\end{array}$ \\
\hline Number of Gyms Per Capita & & $\begin{array}{l}0.128 \\
(2.34 \mathrm{e}-08)\end{array}$ & $\begin{array}{l}0.121 \\
(1.26 \mathrm{e}-07)\end{array}$ & $\begin{array}{l}0.120 \\
(1.34 \mathrm{e}-07)\end{array}$ & $\begin{array}{l}0.119 \\
(1.63 \mathrm{e}-07)\end{array}$ \\
\hline Number of Parks Per Capita & & $\begin{array}{l}0.223 \\
(0.0932)\end{array}$ & $\begin{array}{l}0.211 \\
(0.111)\end{array}$ & $\begin{array}{l}0.214 \\
(0.105)\end{array}$ & $\begin{array}{l}0.205 \\
(0.120)\end{array}$ \\
\hline $\begin{array}{l}\text { Number of Other Rec Areas Per } \\
\text { Capita }\end{array}$ & & 0.0185 & 0.0180 & 0.0189 & 0.0190 \\
\hline & & $(0.0528)$ & $(0.0582)$ & $(0.0471)$ & $(0.0452)$ \\
\hline Cigarette Tax & & $\begin{array}{l}-0.000176 \\
(0.977)\end{array}$ & $\begin{array}{l}-0.000180 \\
(0.977)\end{array}$ & $\begin{array}{l}0.000575 \\
(0.926)\end{array}$ & $\begin{array}{l}-0.00239 \\
(0.701)\end{array}$ \\
\hline Beer Tax & & $\begin{array}{l}-0.110 \\
(0.214)\end{array}$ & $\begin{array}{l}-0.106 \\
(0.228)\end{array}$ & $\begin{array}{l}-0.106 \\
(0.231)\end{array}$ & $\begin{array}{l}-0.113 \\
(0.200)\end{array}$ \\
\hline Overweight & & & $\begin{array}{l}0.00887 \\
(2.26 \mathrm{e}-05)\end{array}$ & $\begin{array}{l}0.00867 \\
(3.48 \mathrm{e}-05)\end{array}$ & $\begin{array}{l}0.00880 \\
(2.60 \mathrm{e}-05)\end{array}$ \\
\hline Obese & & & $\begin{array}{l}-0.0438 \\
(0)\end{array}$ & $\begin{array}{l}-0.0443 \\
(0)\end{array}$ & $\begin{array}{l}-0.0442 \\
(0)\end{array}$ \\
\hline Flu Shot & & & & $\begin{array}{l}0.0169 \\
(0)\end{array}$ & $\begin{array}{l}0.0167 \\
(0)\end{array}$ \\
\hline $\mathrm{n}$ & 436274 & 161127 & 161127 & 161127 & 161127 \\
\hline R-squared & 0.351 & 0.367 & 0.369 & 0.369 & 0.371 \\
\hline
\end{tabular}




\begin{tabular}{|c|c|c|c|}
\hline & $\begin{array}{l}\text { Model 1: } \\
\text { Females } \\
\text { and Males }\end{array}$ & $\begin{array}{l}\text { Model 2: } \\
\text { Female }\end{array}$ & $\begin{array}{l}\text { Model 3: } \\
\text { Male }\end{array}$ \\
\hline Age & $\begin{array}{l}-0.00222 \\
(0)\end{array}$ & $\begin{array}{l}-0.00168 \\
(0)\end{array}$ & $\begin{array}{l}-0.00270 \\
(0)\end{array}$ \\
\hline Age Squared & $\begin{array}{l}7.77 e-06 \\
(1.57 e-08)\end{array}$ & $\begin{array}{l}3.90 e-06 \\
(0.0217)\end{array}$ & $\begin{array}{l}1.09 \mathrm{e}-05 \\
(2.70 \mathrm{e}-06)\end{array}$ \\
\hline Male & $\begin{array}{l}0.0180 \\
(0)\end{array}$ & & \\
\hline Hispanic & $\begin{array}{l}-0.00669 \\
(4.53 e-05)\end{array}$ & $\begin{array}{l}-0.00755 \\
(0.000281)\end{array}$ & $\begin{array}{l}-0.00457 \\
(0.0831)\end{array}$ \\
\hline White & $\begin{array}{l}-0.00194 \\
(0.202)\end{array}$ & $\begin{array}{l}-0.000727 \\
(0.710)\end{array}$ & $\begin{array}{l}-0.00398 \\
(0.0946)\end{array}$ \\
\hline Black & $\begin{array}{l}-0.00395 \\
(0.0548)\end{array}$ & $\begin{array}{l}-0.00700 \\
(0.00640)\end{array}$ & $\begin{array}{l}0.00242 \\
(0.475)\end{array}$ \\
\hline Asian & $\begin{array}{l}-0.0404 \\
(0)\end{array}$ & $\begin{array}{l}-0.0393 \\
(0)\end{array}$ & $\begin{array}{l}-0.0419 \\
(0)\end{array}$ \\
\hline Married & $\begin{array}{l}-0.00804 \\
(0)\end{array}$ & $\begin{array}{l}-0.00724 \\
(0)\end{array}$ & $\begin{array}{l}-0.00777 \\
(3.37 e-09)\end{array}$ \\
\hline High School Diploma & $\begin{array}{l}0.00594 \\
(6.65 \mathrm{e}-05)\end{array}$ & $\begin{array}{l}0.00284 \\
(0.130)\end{array}$ & $\begin{array}{l}0.00927 \\
(0.000117)\end{array}$ \\
\hline Some College & $\begin{array}{l}0.0133 \\
(0)\end{array}$ & $\begin{array}{l}0.0115 \\
(2.38 \mathrm{e}-09)\end{array}$ & $\begin{array}{l}0.0151 \\
(9.27 e-10)\end{array}$ \\
\hline College Degree or More & $\begin{array}{l}0.0245 \\
(0)\end{array}$ & $\begin{array}{l}0.0218 \\
(0)\end{array}$ & $\begin{array}{l}0.0284 \\
(0)\end{array}$ \\
\hline Income $<\$ 10 \mathrm{~K}$ & $\begin{array}{l}-0.0459 \\
(0)\end{array}$ & $\begin{array}{l}-0.0430 \\
(0)\end{array}$ & $\begin{array}{l}-0.0537 \\
(0)\end{array}$ \\
\hline Income $\$ 15 K<\$ 20 K$ & $\begin{array}{l}-0.0395 \\
(0)\end{array}$ & $\begin{array}{l}-0.0392 \\
(0)\end{array}$ & $\begin{array}{l}-0.0404 \\
(0)\end{array}$ \\
\hline Income $\$ 20 K<\$ 25 K$ & $\begin{array}{l}-0.0366 \\
(0)\end{array}$ & $\begin{array}{l}-0.0364 \\
(0)\end{array}$ & $\begin{array}{l}-0.0370 \\
(0)\end{array}$ \\
\hline Income $\$ 25 \mathrm{~K}<\$ 30 \mathrm{~K}$ & $\begin{array}{l}-0.0329 \\
(0)\end{array}$ & $\begin{array}{l}-0.0331 \\
(0)\end{array}$ & $\begin{array}{l}-0.0322 \\
(0)\end{array}$ \\
\hline Income $\$ 30 \mathrm{~K}<\$ 35 \mathrm{~K}$ & $\begin{array}{l}-0.0271 \\
(0)\end{array}$ & $\begin{array}{l}-0.0286 \\
(0)\end{array}$ & $\begin{array}{l}-0.0244 \\
(0)\end{array}$ \\
\hline Income $\$ 35 \mathrm{~K}<\$ 50 \mathrm{~K}$ & $\begin{array}{l}-0.0222 \\
\text { (0) }\end{array}$ & $\begin{array}{l}-0.0219 \\
(0)\end{array}$ & $\begin{array}{l}-0.0218 \\
(0)\end{array}$ \\
\hline Income $\$ 50 \mathrm{~K}<\$ 75 \mathrm{~K}$ & $\begin{array}{l}-0.0146 \\
(0)\end{array}$ & $\begin{array}{l}-0.0153 \\
(0)\end{array}$ & $\begin{array}{l}-0.0133 \\
(0)\end{array}$ \\
\hline Unemployed & $\begin{array}{l}0.00458 \\
(0.0126)\end{array}$ & $\begin{array}{l}-0.00265 \\
(0.248)\end{array}$ & $\begin{array}{l}0.0148 \\
(8.36 \mathrm{e}-07)\end{array}$ \\
\hline Student or Homemaker & $\begin{array}{l}0.0118 \\
(0)\end{array}$ & $\begin{array}{l}0.00993 \\
(0)\end{array}$ & $\begin{array}{l}0.0270 \\
(0)\end{array}$ \\
\hline Retired & 0.0102 & 0.0126 & 0.00692 \\
\hline
\end{tabular}




\begin{tabular}{|c|c|c|c|}
\hline Insured & $\begin{array}{l}-0.000111 \\
(0.927)\end{array}$ & $\begin{array}{l}-0.000833 \\
(0.594)\end{array}$ & $\begin{array}{l}0.00115 \\
(0.549)\end{array}$ \\
\hline Price of Bowling & $\begin{array}{l}-0.00112 \\
(0.494)\end{array}$ & $\begin{array}{l}0.000906 \\
(0.661)\end{array}$ & $\begin{array}{l}-0.00373 \\
(0.161)\end{array}$ \\
\hline Price of Tennis Balls & $\begin{array}{l}0.00603 \\
(3.33 \mathrm{e}-05)\end{array}$ & $\begin{array}{l}0.00732 \\
(6.14 e-05)\end{array}$ & $\begin{array}{l}0.00490 \\
(0.0376)\end{array}$ \\
\hline Price of Gas & $\begin{array}{l}-0.0203 \\
(1.74 \mathrm{e}-10)\end{array}$ & $\begin{array}{l}-0.0237 \\
(3.04 \mathrm{e}-09)\end{array}$ & $\begin{array}{l}-0.0162 \\
(0.00169)\end{array}$ \\
\hline Bus Fare & $\begin{array}{l}0.0107 \\
(2.45 \mathrm{e}-07)\end{array}$ & $\begin{array}{l}0.00645 \\
(0.0137)\end{array}$ & $\begin{array}{l}0.0155 \\
(3.80 \mathrm{e}-06)\end{array}$ \\
\hline Unemployment Rate & $\begin{array}{l}-0.000669 \\
(0.0765)\end{array}$ & $\begin{array}{l}-0.000555 \\
(0.243)\end{array}$ & $\begin{array}{l}-0.000524 \\
(0.391)\end{array}$ \\
\hline Violent Crime Rate & $\begin{array}{l}0.000134 \\
(0.516)\end{array}$ & $\begin{array}{l}0.000137 \\
(0.594)\end{array}$ & $\begin{array}{l}9.78 \mathrm{e}-05 \\
(0.772)\end{array}$ \\
\hline Property Crime Rate & $\begin{array}{l}-2.97 e-05 \\
(0.449)\end{array}$ & $\begin{array}{l}-1.23 e-05 \\
(0.801)\end{array}$ & $\begin{array}{l}-4.74 \mathrm{e}-05 \\
(0.457)\end{array}$ \\
\hline Number of Gyms Per Capita & $\begin{array}{l}0.0212 \\
(0.0229)\end{array}$ & $\begin{array}{l}0.0423 \\
(0.000329)\end{array}$ & $\begin{array}{l}-0.00752 \\
(0.614)\end{array}$ \\
\hline Number of Parks Per Capita & $\begin{array}{l}0.0135 \\
(0.801)\end{array}$ & $\begin{array}{l}-0.00733 \\
(0.914)\end{array}$ & $\begin{array}{l}0.0532 \\
(0.538)\end{array}$ \\
\hline Number of Other Rec Areas Per Capita & $\begin{array}{l}0.0121 \\
(0.00183)\end{array}$ & $\begin{array}{l}0.0128 \\
(0.00963)\end{array}$ & $\begin{array}{l}0.0110 \\
(0.0754)\end{array}$ \\
\hline Cigarette Tax & $\begin{array}{l}-0.00927 \\
(0.000225)\end{array}$ & $\begin{array}{l}-0.00394 \\
(0.213)\end{array}$ & $\begin{array}{l}-0.0149 \\
(0.000247)\end{array}$ \\
\hline Beer Tax & $\begin{array}{l}-0.143 \\
(7.60 \mathrm{e}-05)\end{array}$ & $\begin{array}{l}-0.0982 \\
(0.0330)\end{array}$ & $\begin{array}{l}-0.158 \\
(0.00609)\end{array}$ \\
\hline Overweight & $\begin{array}{l}-0.00611 \\
(0)\end{array}$ & $\begin{array}{l}-0.00920 \\
(0)\end{array}$ & $\begin{array}{l}-0.00225 \\
(0.0994)\end{array}$ \\
\hline Obese & $\begin{array}{l}-0.0231 \\
(0)\end{array}$ & $\begin{array}{l}-0.0244 \\
(0)\end{array}$ & $\begin{array}{l}-0.0211 \\
(0)\end{array}$ \\
\hline Flu Shot & $\begin{array}{l}0.00238 \\
(0.00486)\end{array}$ & $\begin{array}{l}-0.000755 \\
(0.475)\end{array}$ & $\begin{array}{l}0.00660 \\
(1.88 \mathrm{e}-06)\end{array}$ \\
\hline Observations & 383950 & 222823 & 161127 \\
\hline R-squared & 0.221 & 0.195 & 0.257 \\
\hline
\end{tabular}


Table 6: Participation in Moderate or Vigorous Exercise

\begin{tabular}{|c|c|c|c|}
\hline & $\begin{array}{l}\text { Model 1: } \\
\text { Females } \\
\text { and Males }\end{array}$ & $\begin{array}{c}\text { Model 2: } \\
\text { Female }\end{array}$ & $\begin{array}{c}\text { Model 3: } \\
\text { Male }\end{array}$ \\
\hline \multirow[t]{2}{*}{ Age } & -0.000515 & $9.37 e-05$ & -0.00133 \\
\hline & $(0.000778)$ & $(0.638)$ & $(4.98 e-08)$ \\
\hline \multirow[t]{2}{*}{ Age Squared } & $-7.48 e-06$ & $-1.27 e-05$ & $-3.03 e-08$ \\
\hline & $(2.13 e-06)$ & $(4.03 e-10)$ & $(0.990)$ \\
\hline \multirow[t]{2}{*}{ Male } & 0.00884 & & \\
\hline & $(0)$ & & \\
\hline \multirow[t]{2}{*}{ Hispanic } & -0.0134 & -0.0133 & -0.0128 \\
\hline & $(0)$ & $(8.58 e-08)$ & $(9.75 e-06)$ \\
\hline \multirow[t]{2}{*}{ White } & 0.00247 & 0.00526 & -0.00139 \\
\hline & $(0.156)$ & $(0.0247)$ & (0.593) \\
\hline \multirow[t]{2}{*}{ Black } & -0.0106 & -0.0122 & -0.00628 \\
\hline & (6.91e-06) & $(7.38 e-05)$ & $(0.0911)$ \\
\hline \multirow[t]{2}{*}{ Asian } & -0.0477 & -0.0449 & -0.0507 \\
\hline & $(0)$ & $(0)$ & $(0)$ \\
\hline \multirow[t]{2}{*}{ Married } & -0.00540 & -0.00387 & -0.00763 \\
\hline & $(1.21 \mathrm{e}-08)$ & (0.00259) & $(1.13 e-07)$ \\
\hline \multirow[t]{2}{*}{ High School Diploma } & 0.0134 & 0.0106 & 0.0171 \\
\hline & (0) & $(2.19 e-06)$ & $(8.99 e-11)$ \\
\hline \multirow[t]{2}{*}{ Some College } & 0.0206 & 0.0212 & 0.0193 \\
\hline & (0) & (0) & (0) \\
\hline \multirow[t]{2}{*}{ College Degree or More } & 0.0296 & 0.0290 & 0.0310 \\
\hline & $(0)$ & $(0)$ & $(0)$ \\
\hline \multirow[t]{2}{*}{ Income $<\$ 10 \mathrm{~K}$} & -0.0476 & -0.0449 & -0.0515 \\
\hline & $(0)$ & (0) & $(0)$ \\
\hline \multirow[t]{2}{*}{ Income $\$ 15 K<\$ 20 K$} & -0.0403 & -0.0380 & -0.0428 \\
\hline & (0) & (0) & (0) \\
\hline \multirow[t]{2}{*}{ Income $\$ 20 K<\$ 25 K$} & -0.0360 & -0.0345 & -0.0374 \\
\hline & (0) & (0) & (0) \\
\hline \multirow[t]{2}{*}{ Income $\$ 25 \mathrm{~K}<\$ 30 \mathrm{~K}$} & -0.0302 & -0.0296 & -0.0307 \\
\hline & $(0)$ & $(0)$ & $(0)$ \\
\hline \multirow[t]{2}{*}{ Income $\$ 30 \mathrm{~K}<\$ 35 \mathrm{~K}$} & -0.0247 & -0.0255 & -0.0237 \\
\hline & (0) & (0) & $(0)$ \\
\hline \multirow[t]{2}{*}{ Income $\$ 35 \mathrm{~K}<\$ 50 \mathrm{~K}$} & -0.0184 & -0.0173 & -0.0199 \\
\hline & $(0)$ & $(0)$ & $(0)$ \\
\hline \multirow[t]{2}{*}{ Income $\$ 50 \mathrm{~K}<\$ 75 \mathrm{~K}$} & -0.0102 & -0.0104 & -0.0101 \\
\hline & (0) & (1.31e-08) & $(2.26 e-07)$ \\
\hline \multirow[t]{2}{*}{ Unemployed } & 0.0117 & 0.00431 & 0.0217 \\
\hline & (3.08e-08) & $(0.117)$ & (0) \\
\hline \multirow[t]{2}{*}{ Student or Homemaker } & 0.0237 & 0.0218 & 0.0304 \\
\hline & $(0)$ & (0) & (0) \\
\hline
\end{tabular}




\begin{tabular}{|c|c|c|c|}
\hline Retired & $\begin{array}{l}0.0271 \\
(0)\end{array}$ & $\begin{array}{l}0.0262 \\
(0)\end{array}$ & $\begin{array}{l}0.0273 \\
(0)\end{array}$ \\
\hline Insured & $\begin{array}{l}-0.00469 \\
(0.000796)\end{array}$ & $\begin{array}{l}-0.00696 \\
(0.000198)\end{array}$ & $\begin{array}{l}-0.00132 \\
(0.531)\end{array}$ \\
\hline Price of Bowling & $\begin{array}{l}-0.00970 \\
(2.66 \mathrm{e}-07)\end{array}$ & $\begin{array}{l}-0.00710 \\
(0.00402)\end{array}$ & $\begin{array}{l}-0.0141 \\
(1.25 \mathrm{e}-06)\end{array}$ \\
\hline Price of Tennis Balls & $\begin{array}{l}0.00908 \\
(5.20 \mathrm{e}-08)\end{array}$ & $\begin{array}{l}0.0104 \\
(1.89 \mathrm{e}-06)\end{array}$ & $\begin{array}{l}0.00693 \\
(0.00726)\end{array}$ \\
\hline Price of Gas & $\begin{array}{l}-0.0386 \\
(0)\end{array}$ & $\begin{array}{l}-0.0407 \\
(0)\end{array}$ & $\begin{array}{l}-0.0360 \\
(1.80 \mathrm{e}-10)\end{array}$ \\
\hline Bus Fare & $\begin{array}{l}0.0165 \\
(0)\end{array}$ & $\begin{array}{l}0.0110 \\
(0.000446)\end{array}$ & $\begin{array}{l}0.0260 \\
(0)\end{array}$ \\
\hline Unemployment Rate & $\begin{array}{l}-0.000506 \\
(0.242)\end{array}$ & $\begin{array}{l}-0.00137 \\
(0.0160)\end{array}$ & $\begin{array}{l}0.000822 \\
(0.219)\end{array}$ \\
\hline Violent Crime Rate & $\begin{array}{l}0.000420 \\
(0.0759)\end{array}$ & $\begin{array}{l}0.000384 \\
(0.211)\end{array}$ & $\begin{array}{l}0.000467 \\
(0.207)\end{array}$ \\
\hline Property Crime Rate & $\begin{array}{l}-0.000135 \\
(0.00256)\end{array}$ & $\begin{array}{l}-9.06 e-05 \\
(0.122)\end{array}$ & $\begin{array}{l}-0.000187 \\
(0.00751)\end{array}$ \\
\hline Number of Gyms Per Capita & $\begin{array}{l}0.0297 \\
(0.00530)\end{array}$ & $\begin{array}{l}0.0522 \\
(0.000211)\end{array}$ & $\begin{array}{l}0.000939 \\
(0.954)\end{array}$ \\
\hline Number of Parks Per Capita & $\begin{array}{l}0.249 \\
(5.01 \mathrm{e}-05)\end{array}$ & $\begin{array}{l}0.203 \\
(0.0121)\end{array}$ & $\begin{array}{l}0.325 \\
(0.000590)\end{array}$ \\
\hline Number of Other Rec Areas Per Capita & $\begin{array}{l}0.0110 \\
(0.0138)\end{array}$ & $\begin{array}{l}0.0140 \\
(0.0181)\end{array}$ & $\begin{array}{l}0.00648 \\
(0.340)\end{array}$ \\
\hline Cigarette Tax & $\begin{array}{l}-0.0134 \\
(3.23 \mathrm{e}-06)\end{array}$ & $\begin{array}{l}-0.00707 \\
(0.0610)\end{array}$ & $\begin{array}{l}-0.0194 \\
(1.34 \mathrm{e}-05)\end{array}$ \\
\hline Beer Tax & $\begin{array}{l}-0.181 \\
(1.31 \mathrm{e}-05)\end{array}$ & $\begin{array}{l}-0.156 \\
(0.00453)\end{array}$ & $\begin{array}{l}-0.180 \\
(0.00431)\end{array}$ \\
\hline Overweight & $\begin{array}{l}-0.00743 \\
\text { (0) }\end{array}$ & $\begin{array}{l}-0.00907 \\
\text { (0) }\end{array}$ & $\begin{array}{l}-0.00410 \\
(0.00606)\end{array}$ \\
\hline Obese & $\begin{array}{l}-0.0278 \\
(0)\end{array}$ & $\begin{array}{l}-0.0295 \\
(0)\end{array}$ & $\begin{array}{l}-0.0242 \\
(0)\end{array}$ \\
\hline Flu Shot & $\begin{array}{l}0.00234 \\
(0.0160)\end{array}$ & $\begin{array}{l}-0.00134 \\
(0.287)\end{array}$ & $\begin{array}{l}0.00761 \\
(4.98 \mathrm{e}-07)\end{array}$ \\
\hline Observations & 383950 & 222823 & 161127 \\
\hline R-squared & 0.401 & 0.387 & 0.421 \\
\hline
\end{tabular}


Table 7: Participation in any exercise, stratified by income

\begin{tabular}{|c|c|c|c|c|c|c|c|}
\hline & $<10 \mathrm{~K}$ & $\begin{array}{l}10 K- \\
<20 K\end{array}$ & $20 \mathrm{~K}-<25 \mathrm{~K}$ & $25 \mathrm{~K}-<30 \mathrm{~K}$ & $30 K-<35 K$ & $\begin{array}{l}35 \mathrm{~K}- \\
<50 \mathrm{~K}\end{array}$ & $50 \mathrm{~K}-<75 \mathrm{~K}$ \\
\hline Age & $\begin{array}{l}-0.00309 \\
(0.00154)\end{array}$ & $\begin{array}{l}-0.00167 \\
(0.0415)\end{array}$ & $\begin{array}{l}-0.00131 \\
(0.0614)\end{array}$ & $\begin{array}{l}-0.00156 \\
(0.00692)\end{array}$ & $\begin{array}{l}-0.000747 \\
(0.168)\end{array}$ & $\begin{array}{l}0.000657 \\
(0.253)\end{array}$ & $\begin{array}{l}0.00127 \\
(0.00983)\end{array}$ \\
\hline Age Squared & $-4.38 e-06$ & $(0.00806)$ & (0.00117) & (0.00149) & $(0.000128)$ & $\begin{array}{l}-3.52 \mathrm{e}-05 \\
(1.03 \mathrm{e}- \\
08)\end{array}$ & $-3.18 e-05$ \\
\hline Male & $\begin{array}{l}0.0250 \\
(0.000420)\end{array}$ & $\begin{array}{l}0.0309 \\
(7.22 \mathrm{e}- \\
08)\end{array}$ & $\begin{array}{l}0.0239 \\
(4.89 e-07)\end{array}$ & $\begin{array}{l}0.0163 \\
(6.38 \mathrm{e}-06)\end{array}$ & $(8.54 \mathrm{e}-11)$ & 0.0277 & 0.0298 \\
\hline Hispanic & $\begin{array}{l}-0.0592 \\
(3.42 \mathrm{e}-07)\end{array}$ & $\begin{array}{l}-0.0666 \\
(0)\end{array}$ & $\begin{array}{l}-0.0582 \\
(0)\end{array}$ & $\begin{array}{l}-0.0430 \\
(4.16 \mathrm{e}-09)\end{array}$ & $\begin{array}{l}-0.0322 \\
(1.59 \mathrm{e}-06)\end{array}$ & $\begin{array}{l}-0.0166 \\
(0.0160)\end{array}$ & $\begin{array}{l}-0.0194 \\
(0.000964)\end{array}$ \\
\hline White & $\begin{array}{l}0.0150 \\
(0.165)\end{array}$ & $\begin{array}{l}0.00676 \\
(0.461)\end{array}$ & $\begin{array}{l}0.0106 \\
(0.197)\end{array}$ & $\begin{array}{l}0.0124 \\
(0.0721)\end{array}$ & $\begin{array}{l}0.0102 \\
(0.0928)\end{array}$ & $\begin{array}{l}0.00885 \\
(0.155)\end{array}$ & $\begin{array}{l}0.0168 \\
(0.00125)\end{array}$ \\
\hline Black & $\begin{array}{l}-0.0170 \\
(0.260)\end{array}$ & $\begin{array}{l}-0.0320 \\
(0.00926)\end{array}$ & $\begin{array}{l}-0.0478 \\
(1.71 \mathrm{e}-05)\end{array}$ & $\begin{array}{l}-0.0311 \\
(0.000637)\end{array}$ & $\begin{array}{l}-0.0376 \\
(4.32 \mathrm{e}-06)\end{array}$ & $\begin{array}{l}-0.0210 \\
(0.0140)\end{array}$ & $\begin{array}{l}-0.0152 \\
(0.0380)\end{array}$ \\
\hline Asian & $\begin{array}{l}-0.0145 \\
(0.588)\end{array}$ & $\begin{array}{l}-0.0885 \\
(6.45 \mathrm{e}- \\
05)\end{array}$ & $\begin{array}{l}-0.0819 \\
(1.45 e-05)\end{array}$ & $\begin{array}{l}-0.0796 \\
(1.69 e-08)\end{array}$ & -0.0978 & -0.0898 & $\begin{array}{l}-0.0794 \\
(0)\end{array}$ \\
\hline Married & $\begin{array}{l}-0.0187 \\
(0.0171)\end{array}$ & $\begin{array}{l}-0.0313 \\
(9.83 e- \\
08)\end{array}$ & -0.0264 & -0.0184 & $\begin{array}{l}-0.0145 \\
(1.08 \mathrm{e}-06)\end{array}$ & $\begin{array}{l}-0.0122 \\
(4.08 \mathrm{e}- \\
05)\end{array}$ & $\begin{array}{l}0.00136 \\
(0.625)\end{array}$ \\
\hline High School Diploma & $\begin{array}{l}0.0636 \\
(0)\end{array}$ & $\begin{array}{l}0.0596 \\
(0)\end{array}$ & $\begin{array}{l}0.0741 \\
(0)\end{array}$ & $\begin{array}{l}0.0930 \\
(0)\end{array}$ & $\begin{array}{l}0.0777 \\
(0)\end{array}$ & $\begin{array}{l}0.0684 \\
(0)\end{array}$ & $\begin{array}{l}0.0571 \\
(3.72 \mathrm{e}-09)\end{array}$ \\
\hline Some College & $\begin{array}{l}0.113 \\
(0)\end{array}$ & $\begin{array}{l}0.125 \\
(0)\end{array}$ & $\begin{array}{l}0.132 \\
(0)\end{array}$ & $\begin{array}{l}0.151 \\
(0)\end{array}$ & $\begin{array}{l}0.133 \\
(0)\end{array}$ & $\begin{array}{l}0.120 \\
(0)\end{array}$ & $\begin{array}{l}0.102 \\
(0)\end{array}$ \\
\hline College Degree or More & $\begin{array}{l}0.166 \\
(0)\end{array}$ & $\begin{array}{l}0.177 \\
(0)\end{array}$ & $\begin{array}{l}0.179 \\
(0)\end{array}$ & $\begin{array}{l}0.192 \\
(0)\end{array}$ & $\begin{array}{l}0.173 \\
(0)\end{array}$ & $\begin{array}{l}0.159 \\
(0)\end{array}$ & $\begin{array}{l}0.139 \\
(0)\end{array}$ \\
\hline Unemployed & $\begin{array}{l}0.0730 \\
(4.94 \mathrm{e}-10)\end{array}$ & $\begin{array}{l}0.0299 \\
(0.00300)\end{array}$ & $\begin{array}{l}0.0260 \\
(0.00497)\end{array}$ & $\begin{array}{l}0.00403 \\
(0.652)\end{array}$ & $\begin{array}{l}-9.13 e-05 \\
(0.991)\end{array}$ & $\begin{array}{l}-0.0214 \\
(0.0117)\end{array}$ & $\begin{array}{l}-0.00922 \\
(0.211)\end{array}$ \\
\hline Student or Homemaker & $\begin{array}{l}0.0735 \\
(0)\end{array}$ & $\begin{array}{l}0.0555 \\
(4.33 \mathrm{e}- \\
10)\end{array}$ & 0.0533 & $\begin{array}{l}0.0341 \\
(8.79 \mathrm{e}-08)\end{array}$ & $\begin{array}{l}0.0234 \\
(9.67 e-06)\end{array}$ & $\begin{array}{l}0.0255 \\
(2.68 \mathrm{e}- \\
07)\end{array}$ & $\begin{array}{l}0.0157 \\
(1.30 \mathrm{e}-05)\end{array}$ \\
\hline Retired & $\begin{array}{l}0.106 \\
(0)\end{array}$ & $\begin{array}{l}0.0914 \\
(0)\end{array}$ & $\begin{array}{l}0.0764 \\
(0)\end{array}$ & $\begin{array}{l}0.0786 \\
(0)\end{array}$ & $\begin{array}{l}0.0656 \\
(0)\end{array}$ & $\begin{array}{l}0.0608 \\
(0)\end{array}$ & $\begin{array}{l}0.0275 \\
(3.32 \mathrm{e}-09)\end{array}$ \\
\hline Insured & $\begin{array}{l}-0.00498 \\
(0.538)\end{array}$ & $\begin{array}{l}0.00904 \\
(0.170)\end{array}$ & $\begin{array}{l}0.0117 \\
(0.0443)\end{array}$ & $\begin{array}{l}0.0132 \\
(0.00906)\end{array}$ & $\begin{array}{l}0.0193 \\
(0.000127)\end{array}$ & $\begin{array}{l}0.0248 \\
(5.05 \mathrm{e}- \\
05)\end{array}$ & $\begin{array}{l}0.0360 \\
(3.49 \mathrm{e}-09)\end{array}$ \\
\hline Price of Bowling & $\begin{array}{l}0.0124 \\
(0.403)\end{array}$ & $\begin{array}{l}-0.0203 \\
(0.104)\end{array}$ & $\begin{array}{l}0.0111 \\
(0.286)\end{array}$ & $\begin{array}{l}0.00562 \\
(0.478)\end{array}$ & $\begin{array}{l}0.00875 \\
(0.168)\end{array}$ & $\begin{array}{l}-0.00837 \\
(0.142)\end{array}$ & $\begin{array}{l}-0.00464 \\
(0.285)\end{array}$ \\
\hline Price of Tennis Balls & $\begin{array}{l}-0.00301 \\
(0.815)\end{array}$ & $\begin{array}{l}-0.0238 \\
(0.0254)\end{array}$ & $\begin{array}{l}0.0149 \\
(0.0944)\end{array}$ & $\begin{array}{l}-0.00317 \\
(0.639)\end{array}$ & $\begin{array}{l}-0.00283 \\
(0.611)\end{array}$ & $\begin{array}{l}0.00565 \\
(0.270)\end{array}$ & $\begin{array}{l}-0.00519 \\
(0.200)\end{array}$ \\
\hline Price of Gas & $\begin{array}{l}-0.0286 \\
(0.298)\end{array}$ & $\begin{array}{l}-0.0226 \\
(0.328)\end{array}$ & $\begin{array}{l}-0.0306 \\
(0.114)\end{array}$ & $\begin{array}{l}0.000780 \\
(0.958)\end{array}$ & $\begin{array}{l}-0.0171 \\
(0.163)\end{array}$ & $\begin{array}{l}-0.0133 \\
(0.240)\end{array}$ & $\begin{array}{l}-0.00216 \\
(0.810)\end{array}$ \\
\hline Bus Fare & $\begin{array}{l}0.0268 \\
(0.166)\end{array}$ & $\begin{array}{l}0.0234 \\
(0.130)\end{array}$ & $\begin{array}{l}0.0229 \\
(0.0870)\end{array}$ & $\begin{array}{l}0.0106 \\
(0.302)\end{array}$ & $\begin{array}{l}0.0128 \\
(0.123)\end{array}$ & $\begin{array}{l}0.0115 \\
(0.119)\end{array}$ & $\begin{array}{l}0.00813 \\
(0.123)\end{array}$ \\
\hline Unemployment Rate & -0.00573 & -0.00195 & -0.00326 & -0.00276 & -0.00340 & - & -0.00249 \\
\hline
\end{tabular}




\begin{tabular}{|c|c|c|c|c|c|c|c|}
\hline & & & & & & 0.000737 & \\
\hline & $(0.0475)$ & $(0.428)$ & $(0.124)$ & (0.102) & $(0.0211)$ & $(0.605)$ & $(0.0460)$ \\
\hline Violent Crime Rate & -0.00180 & -0.00203 & 0.00112 & -0.00208 & 0.000851 & -0.00171 & -0.000945 \\
\hline & $(0.290)$ & $(0.147)$ & $(0.353)$ & $(0.0277)$ & $(0.282)$ & $(0.0264)$ & $(0.128)$ \\
\hline Property Crime Rate & 0.000276 & $6.69 e-05$ & -0.000594 & 0.000110 & -0.000123 & $8.79 e-05$ & 0.000157 \\
\hline & $(0.389)$ & $(0.804)$ & $(0.00849)$ & $(0.533)$ & $(0.406)$ & $(0.540)$ & $(0.197)$ \\
\hline Number of Gyms Per Capita & -0.0354 & 0.0807 & 0.132 & 0.00579 & 0.0535 & 0.110 & 0.0847 \\
\hline & $(0.658)$ & $(0.226)$ & $(0.0157)$ & $(0.893)$ & $(0.135)$ & (0.00101) & $(0.00165)$ \\
\hline Number of Parks Per Capita & 0.144 & 0.739 & 0.339 & 0.278 & 0.102 & 0.279 & 0.0375 \\
\hline & $(0.744)$ & $(0.0564)$ & $(0.278)$ & $(0.240)$ & $(0.600)$ & $(0.160)$ & $(0.824)$ \\
\hline Number of Other Rec Areas & & & & & & & \\
\hline Per Capita & 0.00330 & -0.00170 & 0.0363 & 0.0414 & 0.0439 & 0.0190 & 0.0158 \\
\hline & $(0.921)$ & $(0.951)$ & $(0.110)$ & (0.0188) & $(0.00247)$ & $(0.166)$ & $(0.182)$ \\
\hline Cigarette Tax & 0.0343 & -0.0230 & -0.0200 & -0.00270 & -0.000160 & -0.0139 & -0.00357 \\
\hline & $(0.124)$ & $(0.208)$ & $(0.200)$ & $(0.822)$ & $(0.987)$ & $(0.121)$ & $(0.594)$ \\
\hline Beer Tax & 0.259 & -0.295 & -0.162 & 0.243 & -0.0663 & 0.0291 & -0.0473 \\
\hline & $(0.416)$ & $(0.249)$ & $(0.458)$ & $(0.148)$ & $(0.626)$ & $(0.818)$ & $(0.652)$ \\
\hline Overweight & -0.00392 & 0.00576 & -0.00190 & -0.00165 & -0.00810 & -0.0138 & -0.0142 \\
\hline & $(0.605)$ & $(0.352)$ & $(0.714)$ & (0.677) & (0.0131) & $\begin{array}{l}(5.35 e- \\
06)\end{array}$ & $(9.97 e-10)$ \\
\hline Obese & -0.0929 & -0.0718 & -0.0816 & -0.0724 & -0.0769 & -0.0701 & -0.0678 \\
\hline & (0) & (0) & (0) & (0) & (0) & (0) & (0) \\
\hline Flu Shot & 0.0163 & 0.0201 & 0.0176 & 0.0132 & 0.0171 & 0.0189 & 0.00835 \\
\hline & $(0.0266)$ & (0.00119) & $(0.000718)$ & (0.00104) & $(2.40 \mathrm{e}-07)$ & $\begin{array}{l}(4.21 \mathrm{e}- \\
10)\end{array}$ & $(0.000219)$ \\
\hline Observations & 20360 & 28299 & 37409 & 55354 & 70065 & 69079 & 84891 \\
\hline R-squared & 0.194 & 0.217 & 0.245 & 0.305 & 0.352 & 0.396 & 0.469 \\
\hline $\begin{array}{l}\text { Standard errors in } \\
\text { parentheses }\end{array}$ & & & & & & & \\
\hline
\end{tabular}

